\title{
First report of Devonian bactritids (Cephalopoda) from South America: paleobiogeographic and biostratigraphic implications
}

\author{
Marcela Cichowolski, ${ }^{1,2}$ and Juan J. Rustán ${ }^{3,4}$ \\ ${ }^{1}$ Universidad de Buenos Aires, Facultad de Ciencias Exactas y Naturales, Departamento de Ciencias Geológicas, Área de Paleontología, Ciudad \\ Universitaria, Pab. 2, C1428EGA, Buenos Aires, Argentina〈mcicho@gl.fcen.uba.ar〉 \\ ${ }^{2}$ CONICET-Universidad de Buenos Aires, Instituto de Estudios Andinos "Don Pablo Groeber" (IDEAN), Buenos Aires, Argentina \\ ${ }^{3}$ Centro de Investigaciones en Ciencias de la Tierra (CICTERRA), Centro de Investigaciones Paleobiológicas (CIPAL), CONICET, Universidad \\ Nacional de Córdoba, Av. Vélez Sarsfield No 1611, X5016GCA, Córdoba, Argentina 〈juanjorustan@ gmail.com〉 \\ ${ }^{4}$ Universidad Nacional de La Rioja, M. de la Fuente s/n, CP 5300, La Rioja, Argentina
}

\begin{abstract}
Devonian bactritids are described for the first time from South America. They come from siliciclastic rocks of the Talacasto Formation in the Precordillera Basin, west-central Argentina. The host strata span the Lochkovian-Emsian and contain other non-ammonoid cephalopods as well, thus refuting the alleged virtual absence of cephalopods in circumpolar Devonian basins from southwestern Gondwana (the Malvinokaffric Realm). We report Bactrites gracilis and Devonobactrites? sp., whose wide distribution contrasts with the endemic paleobiogeographic signature of some other taxonomic groups in these basins. Furthermore, new Lochkovian and Pragian records of Bactrites sp. provide new insights into the earliest bactritid records worldwide.
\end{abstract}

\section{Introduction}

Bactritid cephalopods are considered a key group of the middleupper Paleozoic. In addition to the interesting phylogenetic aspects concerning their origin, their important role in the evolutionary history of cephalopods has been especially debated (e.g., Erben, 1964; Kröger and Mapes, 2007; Kröger et al., 2011; Klug et al., 2015). The present consensus assumes they evolved from an orthocerid group during the latest SilurianEarly Devonian, and, in turn, gave rise to ammonoids during the Devonian and to coleoids in the Mississippian (Erben, 1966; Mapes, 1979; Doguzhaeva, 2002; Kröger and Mapes, 2007; Klug et al., 2015).

In contrast to the rich records from Laurentia and northern Gondwana, bactritids are very poorly known from southern Gondwana. Particularly in South America, the only certain reference is a report of the genus Bactrites Sandberger, 1843 from the Pennsylvanian of Perú (Thomas, 1928). Although Cecioni (1953) reported Eobactrites? from supposedly Early Devonian beds of the Lipeón Formation (Turner, 1960) in northwestern Argentina, that genus is considered a synonym of Bactroceras Holm, 1898 (e.g., Evans, 2005), and accordingly belongs to the Orthocerida (Kröger and Mutvei, 2005). Furthermore, those beds are known to be Silurian in age (Rickards et al., 2002).

A moderately small collection of non-ammonoid cephalopods from the Lower Devonian of west-central Argentina (Precordillera Basin) has recently been studied. Here, we describe bactritid cephalopods, which constitute the first Devonian record of the group in South America. Preliminarily reported orthocerids, pseudorthocerids, and oncocerids from this collection (Cichowolski and Rustán, 2014), as well as recently recognized lamellorthoceratids will be discussed at length in a forthcoming contribution.

With a long history of paleontological investigation, the rich records of the Argentine Precordillera have provided the best source of information on Devonian marine faunas from Argentina (e.g., Vaccari et al., 1994; García-López and Fernández-Martínez, 1995; Herrera, 1995a, b; Sánchez et al., 1995; Herrera et al., 1998; Rustán and Vaccari, 2010, 2012; Rustán et al., 2011a, b; Carrera et al., 2013; Salas et al., 2013; Carrera and Rustán, 2016). However, in spite of this extensive paleontological record, no cephalopods other than the wastebasket genus Orthoceras have been reported from this basin to date (Thomas, 1905; Keidel, 1921; García, 1945; Leidhold and Wetten, 1947).

Paleobiogeographic analyses of Devonian faunas from the Precordillera and elsewhere in southern South America mainly deal with the cold water Malvinokaffric Realm, a major circumpolar austral marine paleobiogeographic unit recognized from the Early-Middle Devonian in southwestern Gondwana (Richter and Richter, 1942). In addition to the high endemism of taxa at the suprageneric level, and the unusual abundance of certain taxonomic groups (such as hyoliths and conulariids), this realm was also characterized by the scarcity (or absence) of several characteristic Paleozoic groups (Boucot and Racheboeuf, 1993). Particularly striking are the lack of stromatoporoids, conodonts, and graptolites, and the extreme scarcity of goniatites.

In this context, a putative "near lack of cephalopods" was cited as a characteristic Malvinokaffric trait (Boucot and Racheboeuf, 1993, p. 72), overlooking a number of compelling reports of Early Devonian non-ammonoid records previously 
confirmed from South Africa, Bolivia, Brazil, the Malvinas Islands, and even from Argentina (see Table 1).

In turn, it has been widely accepted that the imprint of the Malvinokaffric Realm disappeared by the Late Devonian, the earlier endemic faunas being replaced by cosmopolitan elements, due to extrinsic factors such as climatic changes or oceanographic events (Isaacson, 2007). Recent studies from Brazil have proposed the "collapse" of this major paleobiogeographic realm by the Middle Devonian, taking the presence of cephalopods as "immigrant or alien elements" as support of this proposal (Bosetti et al., 2010b, p.62 and references therein).

The relevance of our new records lies mainly in two aspects: the geographic and age distribution of bactritids. The Argentine bactritid records (along with those of other cephalopod groups) provide new insight into their diversity and distribution during the Early Devonian, with implications for some assumptions concerning recognition of the Malvinokaffric Realm as a major paleobiogeographic unit. In addition, since our oldest bactritids come from Lochkovian beds, discussions on their relationship to the earliest records of bactritids are provided.

\section{Stratigraphy and geological setting}

The studied specimens come from the Early Devonian Talacasto Formation in the Argentine Precordillera Basin in west-central Argentina. The Talacasto Formation (Padula et al., 1967) is widely exposed in San Juan Province (Fig. 1.1), but is also known from an isolated outcrop at Sierra de Las Minitas, in La Rioja Province (Fig. 1.2), in the northernmost part of the basin (Rustán et al., 2011a).

Based on records from San Juan Province, the Talacasto Formation is a marine succession of intensely bioturbated greenish-gray mudstones with intercalated beds of sandstone. It typically contains dark argillaceous levels (black to greenish mudstones and shales) basally, passing upwards into sandy levels, with fossiliferous concretions (Figs. 2, 3). According to Astini (1991), this unit corresponds to a muddy shelf depositional system developed during a high stand. It overlies the mainly Silurian shelf deposits of the Los Espejos Formation, and underlies turbiditic deposits of the (mainly) Middle Devonian Punta Negra Formation (Bracaccini, 1950; Bustos and Astini, 1997).

In San Juan Province, the unit increases in thickness from the south (in the type locality at Quebrada de Talacasto), where it is $300 \mathrm{~m}$ thick, to the north (at the Loma de los Piojos section, near Río Jáchal, Fig. 1), where it is more than 1000 m thick. The Talacasto Formation has yielded the majority of the Devonian fossils described from Argentina, including brachiopods (Herrera, 1995a, b; Herrera et al., 1998), trilobites (Vaccari et al., 1994; Rustán and Vaccari, 2010, 2012; Rustán et al., 2011a, b), ostracodes (Salas et al., 2013), corals (García-López and Fernández-Martínez, 1995; Carrera et al., 2013), bivalves (Sánchez et al., 1995), gastropods, and even scarce sponges (Carrera and Rustán, 2016).

As in other closely related Lower-Middle Devonian Malvinokaffric basins, conodonts and graptolites are absent and goniatites are extremely rare in the Precordillera Basin, so that biostratigraphic calibration is based on other fossil groups.

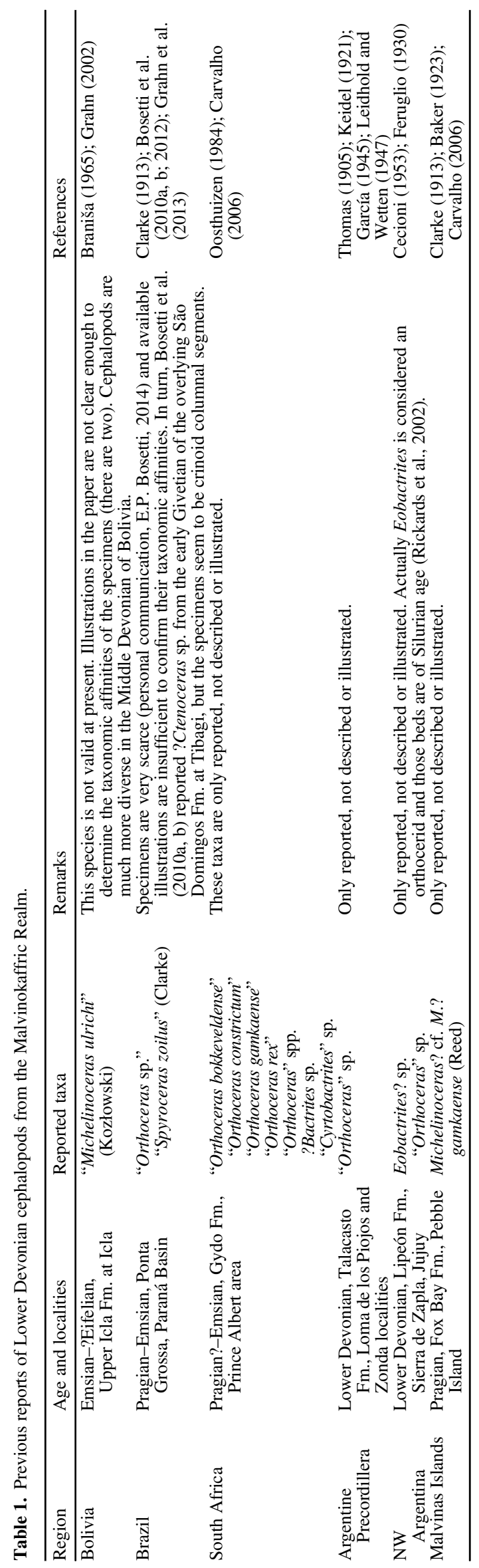



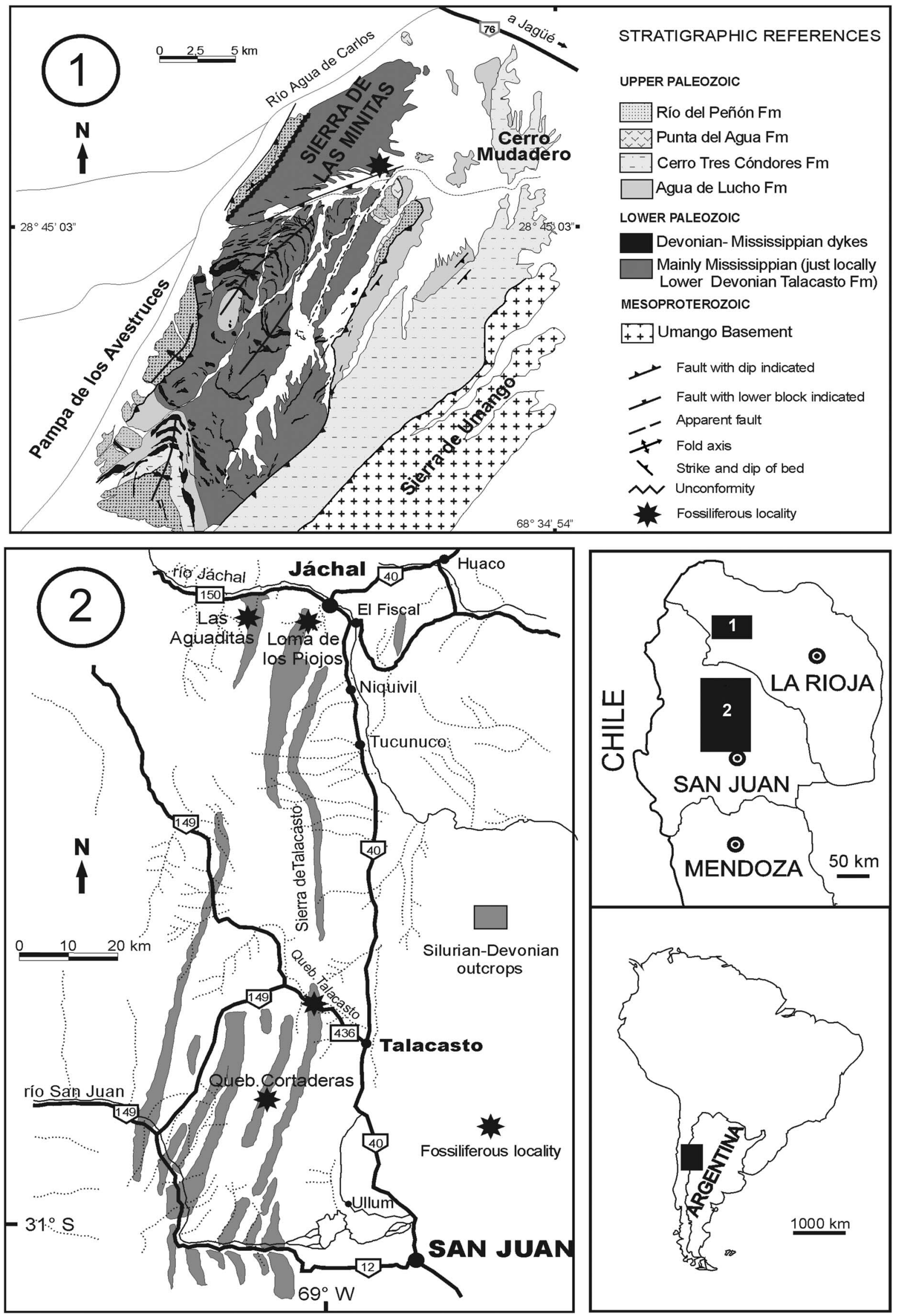

Figure 1. Location of Lower Devonian fossil localities (black stars) in the Precordillera Basin, Argentina: (1) detail of the outcrops at Sierra de las Minitas, La Rioja Province; (2) detail of the outcrops in San Juan Province. 

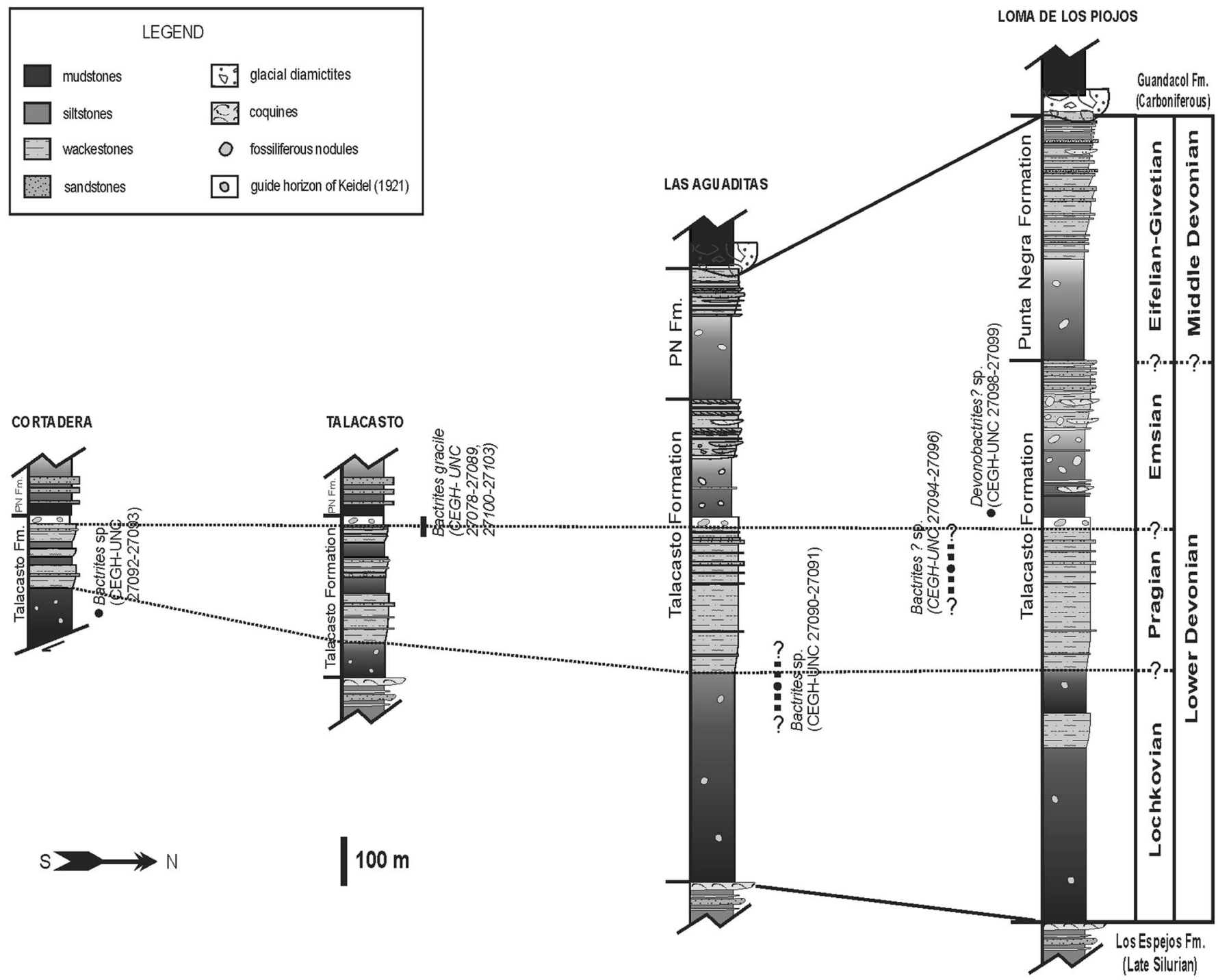

Figure 2. Stratigraphic sections of the Talacasto Formation, showing its diachronic top and the position of the bactritid occurrences.

Thus, an early Lochkovian to late Emsian age has been proposed for the Talacasto Formation based on brachiopod and palynological data (Benedetto et al., 1992; Herrera, 1993, 1995a, b; Lé Herissé et al., 1996; Herrera and Bustos, 2001; García-Muro et al., 2014).

The base of the Devonian is poorly recorded due to a discontinuity between the Los Espejos and Talacasto formations. The Silurian-Devonian boundary can be recognized in the uppermost interval of the Los Espejos Formation in a few localities towards the north of the Talacasto area, near Jáchal (Benedetto et al., 1992; Carrera et al., 2013; García-Muro et al., 2014). In almost all sections, the dark argillaceous lowest stratigraphic interval of the Talacasto Formation has been considered to be early (but not earliest) Lochkovian (Benedetto et al., 1992; Herrera, 1993). According to Herrera (1993), brachiopods supporting a Lochkovian age include Sanjuanetes Racheboeuf and Herrera, 1994, Boucotia Gill, 1969, and Spinoplasia Boucot, 1959. In particular, the genus Sanjuanetes, although endemic from the Andean region, is unknown from strata younger than Lochkovian, based on chitinozoan content from the San Juan borehole (SJN-X2 of YPFB) at the northern part of Santa Cruz de la Sierra, Bolivia (Racheboeuf and Herrera, 1994). Additional palynological data and stratigraphic correlations from equivalent levels at the Cerro del Fuerte and Río Jáchal sections in the Talacasto Formation reinforce this age interpretation (Lé Herissé et al., 1996; García-Muro et al., 2014). Palynomorphs identified by Lé Herissé et al. (1996) in the lower part of the Talacasto Formation, from strata overlying those studied by Benedetto et al. (1992) at Cerro del Fuerte section, agree with this biostratigraphic interpretation since they include the index chitinozoan Urochitina loboi Volkheimer et al., 1986, from levels nearly $53 \mathrm{~m}$ above the base of the unit.

In the case of fossils coming from isolated outcrops corresponding to the argillaceous lower part of the Talacasto Formation in the Sierra de Las Minitas, La Rioja Province, the distinctive association of trilobites (including the rare calmoniid Talacastops zarelae Edgecombe et al., 1994) and its taphonomic signature (infaunal molting in the phacopid Echidnops taphomimus Rustán and Balseiro, 2016) allow a precise correlation with an equivalent low position at the Las Aguaditas 

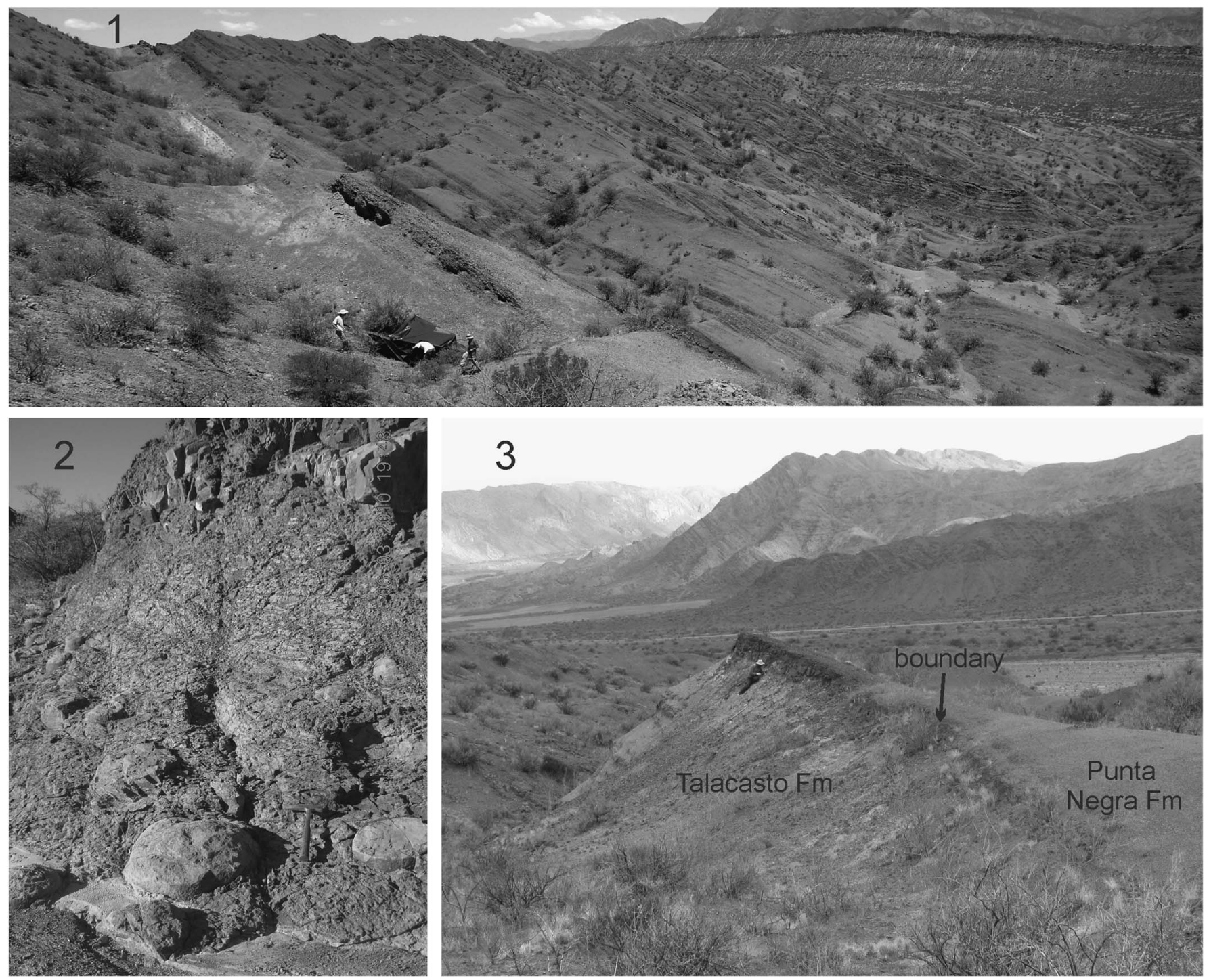

Figure 3. The Talacasto Formation in the field. (1) View to the south showing Keidel's bed in the middle-upper part of the Talacasto Formation at Loma de los Piojos section, near Jáchal. Younger levels are to the right. (2) Detail of the large calcareous fossiliferous concretions of Keidel's bed in the top of the Talacasto Formation at the type locality (Quebrada de Talacasto). Hammer is about $35 \mathrm{~cm}$. (3) View to the south showing Keidel's bed in the top of the Talacasto Formation at the Quebrada de Talacasto section. Emsian green and purple shales of the base of the Punta Negra Formation overlie Keidel's bed. Younger levels are to the right.

section in San Juan Province (Edgecombe et al., 1994), thus supporting a Lochkovian age for the fossiliferous interval (Rustán et al., 2011a, b).

The Lochkovian-Pragian transition has been located near the top of the argillaceous lower stratigraphic interval, based on the stratigraphic ranges of several brachiopods (see Herrera, 1993, 1995b). The overlying level (a sandy stratigraphic interval named the Blue Sandstones Member by Baldis, 1975) has been considered to be mainly Pragian (Herrera, 1993, 1995b). This Pragian age was corroborated by the presence of the trilobite Reedops cf. bronni (Barrande, 1846), otherwise considered a cosmopolitan Pragian biostratigraphic marker (Holloway and Rustán, 2012). Furthermore, the top of this sandy middle stratigraphic interval constitutes the uppermost level of the Talacasto Formation at its type locality (Quebrada de Talacasto) and was referred to the uppermost Pragian by Herrera and Bustos (2001, p. 369), and to the Emsian by Lé Herissé et al. (1996, p. 502).
The very top layer of this interval at the type locality (Quebrada deTalacasto) corresponds to a distinctive ochre-colored, nodulebearing fossiliferous horizon of nearly $10 \mathrm{~m}$ thickness (Fig. 3), which Keidel (1921) and Astini (1991) interpreted as a marker bed. This bed is laterally continuous along more than $100 \mathrm{~km}$ (from Quebrada de Talacasto in the south to Loma de los Piojos in the north) and allows reliable correlation between sections (Fig. 2). Keidel's bed is interpreted to be probably earliest Emsian in age or located around the Pragian-Emsian boundary and, consequently, strata of the Talacasto Formation overlying it (mainly recorded in the thicker northernmost sections of the basin) are considered to be not older than Emsian. In turn, this stratigraphic interpretation has been strengthened by correlation of Keidel's bed with a probably equivalent stratigraphic marker recognized in the subsurface of the Bolivian basins around the Pragian-Emsian boundary, as suggested by Rustán and Vaccari (2010). In addition, the report of the Middle Devonian trilobite Acanthopyge (Lobopyge) balliviani 
(Kozlowski, 1923) nearly $250 \mathrm{~m}$ above Keidel's bed, in the Punta Negra Formation in the Loma de los Piojos section near Jáchal (Rustán and Vaccari, 2010, p. 1084), strongly supports this stratigraphic interpretation.

Thus, the top of the Talacasto Formation should be considered diachronous, with earliest Emsian levels in the southern sections (Quebrada de Talacasto area) and late Emsian or younger levels in the northernmost sections (Río Jáchal area) (Figs. 2 and 3).

\section{Materials and methods}

After new collecting efforts and a revision of previous paleontological collections, we recognized nearly thirty bactritid specimens coming from different localities in the Talacasto Formation (Fig. 1). Surveyed sections in San Juan Province include (from south to north): Quebrada de la Cortadera, Quebrada de Talacasto, Quebrada de Las Aguaditas, and Loma de los Piojos. The single locality in La Rioja Province is the isolated outcrop at the Sierra de las Minitas (Rustán et al., 2011a).

Bactritids were recovered from levels below, within, and directly above Keidel's marker unit. The lowest beds with bactritids correspond to the lower argillaceous interval of the Talacasto Formation (greenish and black mudstones and shales) from the Quebrada de la Cortadera and Sierra de las Minitas localities, which are considered Lochkovian in age (Benedetto et al., 1992; Herrera, 1993; Rustán et al., 2011a). Thus, the stratigraphic range of bactritids in the Talacasto Formation spans from the Lochkovian to the Emsian, presuming the stratigraphic interpretation is correct.

The preservation of specimens differs depending on the lithology and locality. Fossils are preserved either in the clayey mudstone matrix or inside small nodules in the lower argillaceous interval, in massive grayish sandstones just below Keidel's bed, within large (up to $50 \mathrm{~cm}$ ) calcareous nodules within
Keidel's bed, and in greenish mudstones in the upper part of the unit. Some consist of internal molds of incomplete phragmocones or body chambers. In these cases, the usually poor, fragmentary preservation does not allow further taxonomic determination. However, specimens from Keidel's level preserve phragmocones with part of the body chamber, frequently exhibiting complete remains of the septa, siphuncle, shell wall, which provides information on the ornamentation and morphology of the early ontogenetic stages.

Specimens were prepared using pneumatic "vibro-tools" and needles under a binocular microscope. Polished sections were also prepared. In some cases, silicon-rubber casts were made in order to see the ornamentation. Both fossils and rubber casts were sometimes coated with black Chinese ink and then coated with ammonium chloride sublimate before they were photographed.

In some cases, the external shell was treated with $30 \%$ chlorhydric acid to uncover the sutures. Uncoated specimens were photographed dry, submersed in water or alcohol, or covered with vaseline (particularly those cut and polished), using a Canon Power Shot S50 digital camera mounted on a Leica MZ75 binocular loupe.

Characters measured are set out in the explanation of Table 2. All measurements were taken using digital calipers with a resolution of $0.1 \mathrm{~mm}$.

Repositories and institutional abbreviations.-The material from San Juan Province is housed under the prefix CEGH-UNC in the paleontological collections of the CIPAL (Centro de Investigaciones Paleobiológicas, Córdoba, Argentina), at the building of the CICTERRA (Centro de Investigaciones en Ciencias de la Tierra), CONICET-Universidad Nacional de Córdoba, Córdoba, Argentina. The material from La Rioja Province is housed under the prefix PULR-I in the Museo de Ciencias Naturales of the Universidad Nacional de La Rioja, La Rioja, Argentina.

Table 2. Measurements of Bactrites gracilis (Blumenbach, 1803) and Bactrites sp. from the Lower Devonian Talacasto Formation, Argentine Precordillera. The stratigraphic position of each specimen is detailed in the Systematic Paleontology section. $\mathrm{LF}=$ length of the fragment; Dia ${ }_{\text {or }}=$ conch diameter at adoralmost preserved end; $\mathrm{Dia}_{\mathrm{ap}}=$ conch diameter at adapicalmost preserved end (usually the diameter measured laterally or dorsoventrally doesn't differ significantly, therefore we took just one value), units $=\mathrm{mm} ; \mathrm{AA}=$ apical angle $=$ tangents ${ }^{-1}$ of the expansion rate $\left(\mathrm{Dia}_{\text {or }}-\mathrm{Dia}_{\mathrm{ap}}\right) / \mathrm{distance}$ between both diameters), unit $=$ degrees; $\mathrm{Si}$. Dia. = siphuncle diameter = ratio of the siphuncle diameter to the conch diameter at the same point of measure, expressed as a percentage; Sep. Dep. $=$ septal depth $=$ ratio of the distance between the plane of the suture and the culmination of the septum to the diameter of the phragmocone at the same point expressed as a percentage; L.Li.Cham. = length of the preserved fragment of the body chamber, unit $=$ mm; Cam. Rat. $=$ cameral ratio $=$ ratio of the diameter to the length of the chambers (or the number of camerae in a distance equivalent to the conch diameter at the same ontogenetic stage). Sometimes there is a range of measurements; we put them as $\mathrm{a}-\mathrm{b}$, indicating the minimum and the maximum values. $* *$ CEGH-UNC 27082 consists of a few disaggregated chambers. *Approximate measures because of poor preservation or deformation.

\begin{tabular}{|c|c|c|c|c|c|c|c|c|c|}
\hline specimen & taxonomic assignment & $\mathrm{LF}(\mathrm{mm})$ & $\mathrm{Dia}_{\mathrm{or}}(\mathrm{mm})$ & $\operatorname{Dia}_{\mathrm{ap}}(\mathrm{mm})$ & $\mathrm{AA}\left({ }^{\circ}\right)$ & Si. Dia. (\%) & Sep. Dep. (\%) & L.Li.Cham & Cam. Rat. \\
\hline$\overline{\mathrm{CEGH}-U N C} 27103$ & Bactrites gracilis & 112.4 & 6.6 & 0.5 & 3.1 & $13-15$ & 27 & 44.0 & $1.3-1.8$ \\
\hline CEGH-UNC 27080 & Bactrites gracilis & 42.0 & 5.6 & 3.0 & 3.5 & 15 & - & $?$ & $1.1-1.3$ \\
\hline CEGH-UNC 27081 & Bactrites gracilis & 35.0 & 5.0 & 3.1 & 3.1 & 16 & - & - & $1.6-2.0$ \\
\hline CEGH-UNC 27082 & Bactrites gracilis & $* *$ & 5.8 & 5.5 & - & $9-12$ & 25 & - & $1.8-2.0$ \\
\hline CEGH-UNC 27083 & Bactrites gracilis & 12.2 & 5.4 & 4.8 & 2.8 & 9 & 23 & - & $1.7-1.8$ \\
\hline CEGH-UNC 27084 & Bactrites gracilis & 5.5 & 4.0 & 3.6 & 4.0 & - & - & - & - \\
\hline CEGH-UNC 27085 & Bactrites gracilis & 28.7 & 4.7 & 3.2 & 3.0 & 12 & 32 & $?$ & $?$ \\
\hline CEGH-UNC 27086 & Bactrites gracilis & 12.3 & - & 5.4 & - & 14 & 20 & - & 1.8 \\
\hline CEGH-UNC 27087 & Bactrites gracilis & 6.6 & 3.6 & 3.1 & 4.3 & 16 & 38 & - & 1.8 \\
\hline CEGH-UNC 27088 & Bactrites gracilis & 5.2 & 3.9 & 3.6 & 3.8 & 13 & 28 & - & 2.6 \\
\hline CEGH-UNC 27089 & Bactrites gracilis & 37.5 & 7.4 & 5.2 & 3.4 & 14 & 30 & 12.5 & $2.0-2.5$ \\
\hline CEGH-UNC 27090 & Bactrites sp. & 23.7 & 7.6 & 6.0 & 3.7 & 15 & 20 & $23.7 ?$ & - \\
\hline CEGH-UNC 27091 & Bactrites sp. & 8.0 & 7.9 & 7.0 & $6.4^{*}$ & 10 & 10 & - & 0.7 \\
\hline PULR-I 1 & Bactrites sp. & 32.3 & 10.0 & 6.8 & 5.7 & 10 & 42 & $30 ?$ & - \\
\hline CEGH-UNC 27092 & Bactrites sp. & 9.3 & 4.1 & $3.4^{*}$ & $4.3^{*}$ & 10 & - & - & 2.0 \\
\hline
\end{tabular}




\section{Systematic paleontology}

Class Cephalopoda Cuvier, 1797

Subclass Neocephalopoda Lehmann and Hillmer, 1980

Superorder Bactritida Shimansky, 1951

Family Bactritidae Hyatt, 1884

Genus Bactrites Sandberger, 1843

Type species.-Bactrites subconicus Sandberger, 1843, from the Wissenbach Slate, Eifelian of Wissenbach, Germany.

Bactrites gracilis (Blumenbach, 1803)

Figures 4.1-4.16, 5.1-5.12

1803 Orthoceras gracile Blumenbach, pl. 2, fig. 6.

1843 Bactrites gracilis sp. nov. [junior synonym] Sandberger, pl. 8, fig. 2.

1968 Bactrites schlotheimi (Quenstedt); Clausen, p. 58, pl. 7.

2005 Bactrites gracile (Blumenbach); Kröger et al., p. 331, fig. 1a [with synonymy].

2008 Bactrites gracile (Blumenbach); Kröger, p. 95, pl. 14, fig. 12.

Holotype.-The holotype by monotypy of Orthoceras gracile Blumenbach, 1803, is lost. That specimen came from the Harz Mountains (probably from the Goslar Slate), which are mostly, but incorrectly synonymyzed with the Wissenbach Slate (personal communication, R.T. Becker, 2016). Bactrites gracilis Sandberger, 1843, should be interpreted as a subjective junior synonym of Orthoceras gracile of Blumenbach (1803). Hence, although Clausen (1968) selected a lectotype for B. schlotheimii (a nominal taxon originally proposed by Quenstedt, but considered invalid by Kröger et al. [2005], because of its lack of a description) using a Sandberger syntype (Sandberger and Sandberger, 1850-1856, pl. 11, fig. 9), this nomenclatural act should be interpreted as sorting of a type of $B$. gracilis Sandberger, not as erection of a lectotype for $O$. gracile Blumenbach. Accordingly, a neotype from the Harz Mountains is required for B. gracilis (Blumenbach).

Materials.-Sixteen specimens from Quebrada de Talacasto, San Juan Province. CEGH-UNC 27078-88 and 27103 from Keidel's bed (latest Pragian?-earliest Emsian), CEGH-UNC 27100-02 from a level 5 m below Keidel's bed (latest Pragian or earliest Emsian), and CEGH-UNC 27089 from nearly $30 \mathrm{~m}$ below Keidel's bed (Pragian). Collector: JJR.

Description.-Orthoconic and longiconic conchs, with a maximum preserved length of $112.4 \mathrm{~mm}$ (CEGH-UNC 27103). In the most complete specimen, the body chamber occupies $40 \%$ of the total length (Fig. 4.1). The apical angle ranges from $2.8^{\circ}$ to $4^{\circ}$ and the cameral ratio from 1.1 to 2.6 , with 1.8 being the most common measurement (Table 2). The maximum orad diameter is $7.4 \mathrm{~mm}$ in CEGH-UNC 27089. The siphuncle is small and marginal, in a ventral position, with a relative diameter 9-16\% of the conch diameter. The septal perforation is orthochoanitic (Figs. 4.3, 4.14, 4.15, and 5.10-5.12). The septal depth ranges from $20 \%$ to $38 \%$. The conch cross section is usually subcircular, but in a few cases it appears to be faintly compressed.
It can be seen changing even in the same specimen throughout the ontogeny (Figs. 4.9, 4.13, 5.4). The suture is straight laterally and dorsally, with a small V-shaped ventral lobe that has varying depths and widths, probably depending on preservation (Figs. 4.7, 4.11, 5.1, 5.8). This lobe is present even in very small chambers, such as those in the adapical part of CEGH-UNC 27103, which are only $0.5 \mathrm{~mm}$ in diameter (Fig. 4.4). The septa sometimes appear to be slightly inclined (e.g., Fig. 4.12). Almost all specimens lack the apicalmost part, but chambers adjacent to the apex are visible in CEGH-UNC 27103. They are $0.4 \mathrm{~mm}$ long and $0.5 \mathrm{~mm}$ wide (Fig. 4.4). The surface of the shell is usually smooth or it displays, especially on body chamber parts, impressed growth lines or very faint and rounded ribs that form an adoral inflexion on the dorsum, crossing obliquely over the flanks, and finally showing an adapical inflection in the ventral part, probably representing the hyponomic sinus (Fig. 4.2, 4.5).

Remarks.-The combination of morphological characters, such as the apical angle, cameral ratio, the straight suture with ventral lobe, and nearly circular cross section, suggest that the Argentine specimens can be assigned to Bactrites gracilis (Blumenbach, 1803). The diagnosis of B. gracilis in Kröger (2008, p. 95) stated: "initial chamber ovate, smooth, with circular cross-section, c. $0.9 \mathrm{~mm}$ wide and $1.2 \mathrm{~mm}$ long; ovate shape of initial chamber highly variable." Considering that in the Bactritida the embryonic conch has a wider diameter than the subsequent chamber, it seems probable that chambers here described with a width of $0.5 \mathrm{~mm}$ correspond to the adjacent chambers following the initial one. Although we don't know the shape of the initial chamber in our material, we think that the overall description fits well with this species of Bactrites. Otherwise, these organisms have so few distinguishable characters that small variations possibly of intraspecific origin could split them artificially into several taxa of dubious value.

\section{Bactrites sp.}

Figure 5.13-5.21

Materials.-Five specimens: CEGH-UNC 27090 from Quebrada de las Aguaditas, San Juan Province, argillaceous lower interval (Lochkovian?-Pragian?), fossiliferous level 5 of collector Z. Herrera. CEGH-UNC 27091 from the lower interval of the Quebrada de las Aguaditas section, (Lochkovian?Pragian?), fossiliferous level 5-6 of collector Z. Herrera. CEGH-UNC 27092 from the lower argillaceous interval of the Quebrada de la Cortadera section (Lochkovian), San Juan Province, fossiliferous level 14 of the degree work of collector M.J. Salas (1995, p. 63). PULR-I 1-2 from the Sierra de las Minitas, La Rioja Province, Lochkovian argillaceous lower interval (Rustán et al., 2011a).

Description.-Orthoconic and longiconic conchs with angle of expansion ranging from $3.7^{\circ}$ to almost $6.4^{\circ}$. Conch cross section subcircular to ovate (Fig. 5.13, 5.20), with small and marginal siphuncle (diameter $10-15 \%$ of the conch diameter). Septal depth variable, and cameral ratio (measured in two specimens) 0.7-2.0 (Table 2). Sutures straight with V-shaped ventral lobe (Fig. 5.14, 5.16, 5.17, 5.21). CEGH-UNC 27090 and 


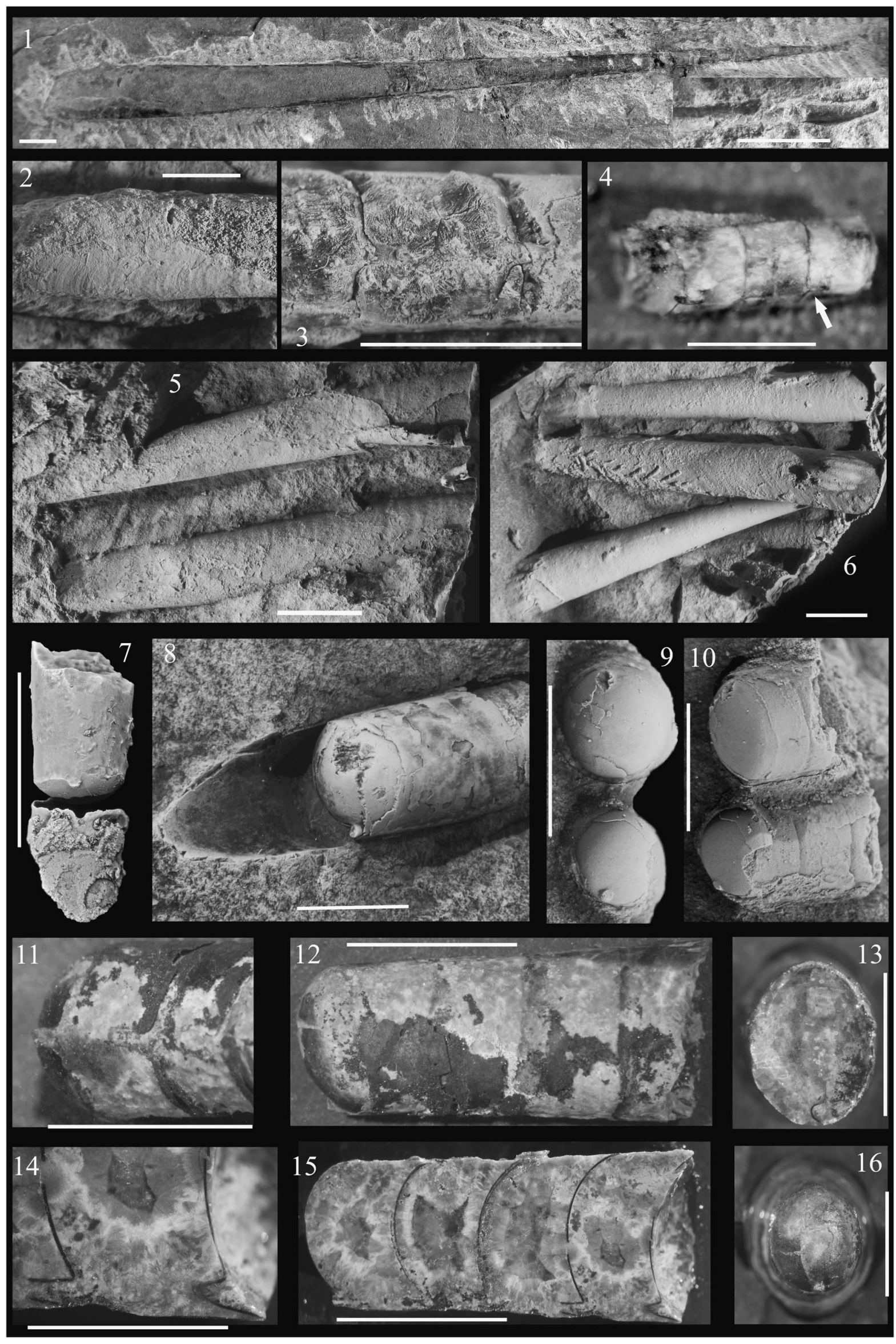


PULR-I 1-2 are preserved as possible body chambers (internal molds) with the last-formed septum preserved, in which the siphuncle is visible. CEGH-UNC 27091 is an isolated phragmocone chamber, thus its measurements should be taken cautiously. CEGH-UNC 27092, which would be the regionally oldest bactritid, is a partial phragmocone with the ventral sutures exposed, in which the small ventral lobe can be seen (Fig. 5.14).

Remarks.-We assign these specimens to the genus Bactrites, although it seems inappropriate to assign them to a species because their preservation is rather poor. The slender form of the conchs, the straight suture with a ventral lobe, subcircular to slightly ovate cross section, and the values of the cameral ratio are typical for the genus. We are not sure that all specimens belong to one species due to differences of cross sections and septal curvatures.

Among the specimens with clear characters typical of the Bactritidae, at least six should be considered as Bactrites? (doubtfully) mainly because the siphuncle is not preserved: CEGH-UNC 27093 from Quebrada de la Cortadera, from fossiliferous level 14 (Lochkovian) of Salas (1995), CEGHUNC 27094-96 from the Loma de los Piojos section, San Juan Province, from a stratigraphic interval $30-40 \mathrm{~m}$ below Keidel's bed, fossiliferous level 41 of collector B. Waisfeld (Pragian), CEGH-UNC 27097 from the Loma de los Piojos section, from mudstones above Keidel's bed (Emsian), and PULR-I 3 from the Sierra de las Minitas, La Rioja Province, Lochkovian lower argillaceous interval. Nevertheless, the general shape of the fragments and their proportions strongly suggest they belong to Bactrites as well. In spite of the open nomenclature, the main interest of these records is the age of the host beds, considered to be Lochkovian to Pragian (except CEGH-UNC 27097). Given that we have no data about the apical part of these specimens, we cannot clarify their relations with the Emsian material. The presence of those traits considered "bactritid-like," such as the ventral lobe of the suture and the small, ventral siphuncle in "Bactrites" bohemicus Ristedt (in Ristedt, 1981), was considered homeomorphism by Kröger and Mapes (2007) and Klug et al. (2015). However, we believe that the fact that they were found within one stratigraphic section suggests these pre-Emsian specimens are most probably bactritids as well.

Genus Devonobactrites Shimansky, 1962

Type species.-Orthoceratites obliquiseptatum Sandberger and Sandberger, 1852, from the Wissenbach Slate, Eifelian of Wissenbach, Germany.
Devonobactrites? sp.

Figure 5.22-5.24

Materials.-Two specimens from the Loma de los Piojos section, San Juan Province. CEGH-UNC 27098, and CEGHUNC 27099, greenish mudstones nearly $5 \mathrm{~m}$ above Keidel's bed (Emsian), collectors: R.T. Becker, C. Klug and B. Kröger.

Description.-Specimen CEGH-UNC 27099 is a $3.4 \mathrm{~mm}$ long and $\sim 3 \mathrm{~mm}$ wide fragment of an incomplete phragmocone consisting of a few small chambers. It was deformed by compaction in a nearly lateral sense (Fig. 5.23, 5.24). This deformation probably accentuated the originally slightly compressed cross section. The septa appear to be somewhat oblique, but due to deformation of the specimen, it is not clear whether this represents their original orientation. The siphuncle is small, with a width of $11 \%$ conch diameter, and it is not fully marginal. The cameral length is $\sim 2 \mathrm{~mm}$. The shell wall is not preserved. CEGH-UNC 27098 is a longer fragment of a broken and deformed conch. It is impossible to determine whether parts of the body chamber are present (Fig. 5.22). Its deformation is in the dorsoventral plane, resulting in an artificially depressed section. The siphuncle diameter is $\sim 14 \%$ of the conch diameter. The measured apical angle is $\sim 4.4^{\circ}$. The shell wall is poorly preserved and the ornamentation appears to be composed of faint, oblique undulations. The sutures are hardly distinguishable, although on the venter, they appear to be slightly inclined, as seen in the most adapical septum.

Remarks.-The incomplete and poor preservation of these specimens precludes measurement or evaluation of characteristics typical of the genus or individual species (e.g., close septal spacing or the shape of the embryonic conch). The oblique septa and the sub-marginal siphuncle suggest the specimens could be included in the genus Devonobactrites. Better-preserved material is needed to evaluate the affinities of this form. In comparison with records lower in the same formation, they are conspicuously small. The bigger bactritids collected from beds below Keidel's level are more robust.

\section{Discussion}

Paleobiogeography.-Devonian records of Malvinokaffric endemic marine faunas correspond to southwestern Gondwanan basins (Boucot and Racheboeuf, 1993), including those from South America, excepting Venezuela and Colombia (Morzadec et al., 2015), Antarctica, Ghana, and South Africa (Fig. 6).

\footnotetext{
Figure 4. (1-16) Bactrites gracilis (Blumenbach, 1803), from latest Pragian?-earliest Emsian levels of the Talacasto Formation at the Quebrada de Talacasto section, San Juan Province, Argentina. All from calcareous sandy nodules from Keidel's bed, except (6) from nearly $5 \mathrm{~m}$ below it. (1-4) CEGH-UNC 27103, ventral view of nearly complete specimen, detail of the sinuous growth lines defining a ventral sinus, detail of the orthochoanitic septal necks, and ventrolateral view of three chambers adjacent to the apical part, without shell wall. The arrow points to the ventral lobe of the suture; (5) latex cast of CEGH-UNC 27084 (on top) and CEGHUNC 27083 (at bottom), lateral views showing the sinuous growth lines; (6) latex cast of CEGH-UNC 27100 (on top), CEGH-UNC 27101 (in the middle) and CEGH-UNC 27102 (at bottom), note the sinuous growth lines and bryozoan epizoans; (7) ventral view of CEGH-UNC 27084, recrystallized and incomplete phragmocone showing the ventral lobe; (8) posterolateral view of CEGH-UNC 27086, fragmentary specimen with partially preserved shell wall; (9) CEGH-UNC 27088 (on top) and CEGH-UNC 27087 (at bottom) in posterior view, incomplete phragmocones showing the spherical septa and the siphuncle; (10) the same specimens in posterolateral view, note the straight sutures; (11-16) CEGH-UNC 27083, incomplete phragmocone in ventral view showing details of the sutures and the siphuncle, detail of the sutures in lateral view (note the adapical inclined suture), anterior view (note the compressed cross section), longitudinal polished section showing detail of the orthochoanitic septal necks, general view of the longitudinal polished section showing the relatively long chambers and the ventral and small siphuncle, and posterior view with details of the compressed cross section. Scale bars = $1 \mathrm{~mm}(\mathbf{4})$, or $2.5 \mathrm{~mm}(\mathbf{1 4})$, or $5 \mathrm{~mm}(\mathbf{1 - 3}, \mathbf{5 - 1 3}, \mathbf{1 5}, \mathbf{1 6})$.
} 


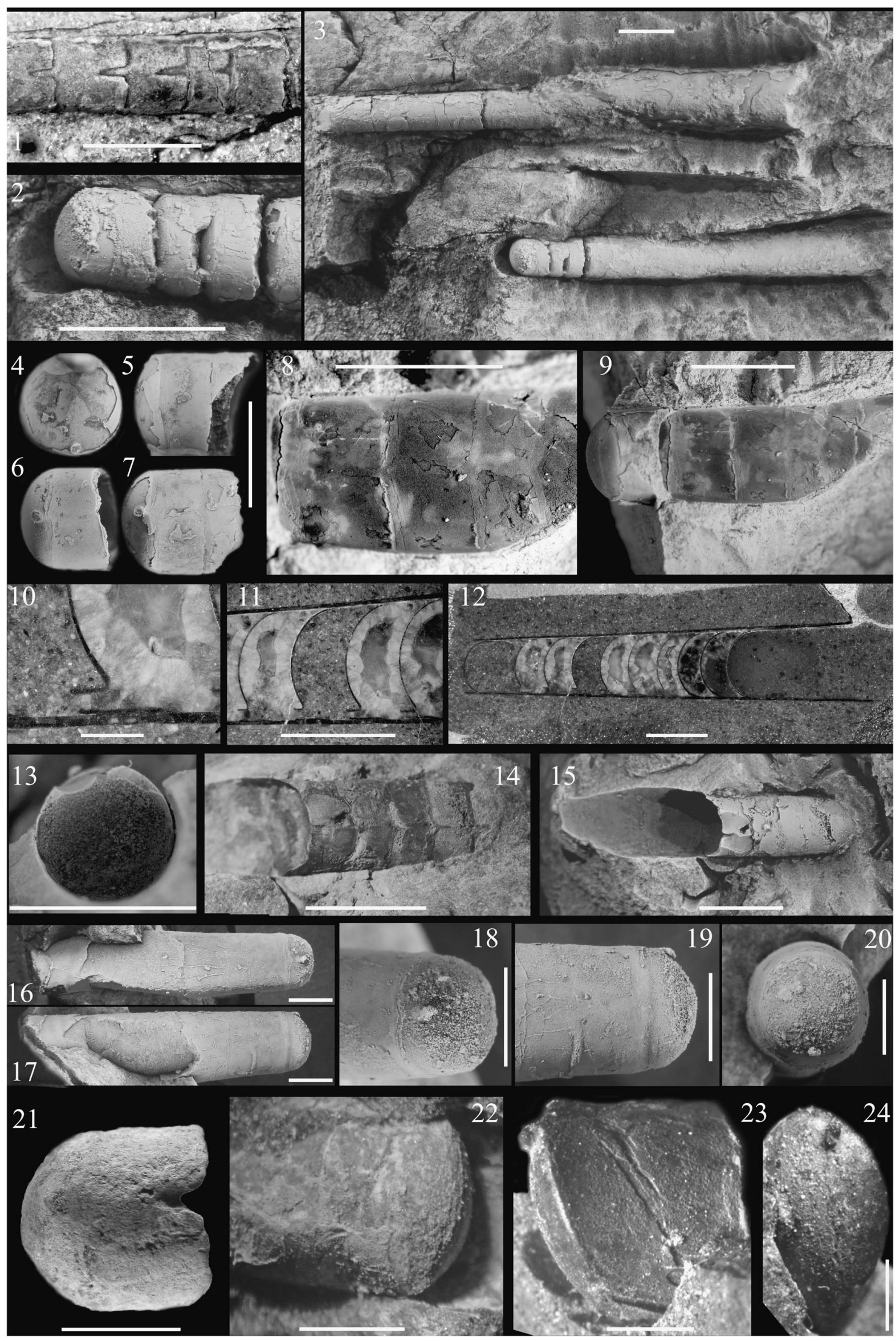


A number of Lower and Middle Devonian cephalopod records have been known from these basins since the early twentieth century, yet their paleobiogeographic affinities are still poorly known, pending a more exhaustive taxonomic revision.

In Argentina, with the exception of the putative records of Devonian cephalopods from the NW area (proven to be Silurian by Rickards et al., 2002), the wastebasket genus Orthoceras constitutes the main taxon cited from the Lower Devonian of the Argentine Precordillera (see summary in Castellaro, 1966). Otherwise, the rare ammonoid Tornoceras baldisi Leanza, 1968, from the Middle Devonian Chigua Formation is the only other Devonian cephalopod reported from Argentina (Leanza, 1968). In addition, Clarke (1913) and Baker (1923, cited in Castellaro, 1966) reported Michelinoceras? from the Lower Devonian of the Malvinas Islands.

Michelinoceras was reported from the Early Devonian Icla Formation at Sucre in Bolivia, but the higher diversity and abundance here corresponds to the Middle Devonian (Braniša, 1965; Troth et al., 2011).

"Orthoceras" has also been reported from the Emsian of South Africa (Oosthuizen, 1984), along with ?Bactrites and "Cyrtobactrites." Two wastebasket taxa were reported from the Emsian of the Paraná Basin in Brazil: Orthoceras and Spyroceras (Bosetti et al., 2010b, 2012).

Table 1 summarizes the non-ammonoid cephalopods reported from this region. The large number of published specimens contradicts the hypothesis (mainly stated by Boucot and Racheboeuf, 1993) that nautiloid cephalopods were virtually absent in Early and Middle Devonian Malvinokaffric associations. In fact, based on this misconception and local evidence from the Paraná Basin, Bosetti et al. (2010b) argued that the presence of cephalopods in early Givetian beds indicates that the Malvinokaffric Realm collapsed during the Middle Devonian due to the rising marine temperature. However, through palynological analysis in Bolivia, Troth et al. (2011) demonstrated that the climate continued to be cold through the Middle and Late Devonian, and that immigration of warmer water Malvinokaffric taxa (e.g., the brachiopod Tropidoleptus) was due to discrete transgressive events in South America rather than a permanent immigration process. In spite of this, the cephalopods were interpreted as immigrants or alien taxa and used as evidence for a great paleobiogeographic change during the Eifelian-Givetian transition, overlooking the previous records of cephalopods from Lower Devonian strata in southwestern Gondwana. In addition, fossils assigned to ?Ctenoceras are almost certainly crinoid stems. Indeed, they exhibit a homogeneous diameter, homogeneous distance between supposed "sutures," and no evidence of an aperture, chambers, or embryonic conch, but exhibit the constrictions and annulated, ridged ornamentation that characterize crinoid columnals (Bosetti et al., 2010a, figs. 7e, 7f; Bosetti et al., 2010b, figs. 6I-6L; Horodyski et al., 2013, figs. 6b, 6f). Ctenoceras, in turn, is an Ordovician genus (Kröger, 2004). On the other hand, some of these fossils have been interpreted as "roll marks" by the same authors, including some specimens which exhibit the typical "zig-zag" articulations usually visible in crinoid stems (Bosetti et al., 2010b, fig. 6L; Horodyski et al., 2013, fig. 6f). Thus, there is no reliable evidence of cephalopods in the units studied and the hypothesis of a Middle Devonian collapse of the Malvinokaffric Realm, as proposed by those authors, should be revised.

The available evidence from southwestern Gondwana contrasts markedly with the hypothesis of a virtual absence of cephalopods in the Malvinokaffric Realm. It is worth mentioning that the bactritids described herein are associated with orthoceratoids (orthocerids, pseudorthocerids, lituitids) and oncocerids. In particular, it is remarkable that the lituitid family Lamellorthoceratidae Teichert, 1961 is present, a group which previously has only been reported from warmer regions such as Morocco (Termier and Termier, 1950; Kröger, 2008), France (Teichert, 1961; Babin, 1964), Germany (Beyrich, 1850), Bohemia (Kolebaba, 1999), Russia (Zhuravleva, 1961, 2006), North America (Stanley and Teichert, 1976; Bandel and Stanley, 1989), Turkey, and Japan (Niko, 2001). Recognition herein of the widely distributed bactritid taxa Bactrites gracilis and Devonobactrites agrees with the lamellorthoceratid distribution. Bactrites is a cosmopolitan taxon, and B. gracilis was reported from the late Emsian-Givetian of Morocco, Germany, the United Kingdom, and USA (Kröger, 2008). Devonobactrites is known from the early Emsian-early Eifelian of Germany and Morocco (Kröger, 2008; Klug et al., 2010).

Because its faunas were established in isolated tectonic basins, the Malvinokaffric Realm has been considered as a natural model to evaluate the relationships among the spatial distribution of taxa, the geologic history of a region, and

\footnotetext{
Figure 5. (1-12) Bactrites gracilis (Blumenbach, 1803) from the Early Devonian Talacasto Formation, San Juan, Argentina: (1-9) specimens from Keidel's bed (latest Pragian?-earliest Emsian) at the Talacasto section; (10-12) specimen from grayish sandstones $30 \mathrm{~m}$ below Keidel's bed (late Pragian?) at the Talacasto section. (1) CEGH-UNC 27080, incomplete phragmocone without shell wall showing the sutures with their small ventral lobes; (2) CEGH-UNC 27081, incomplete phragmocone with partially disarticulated chambers in ventrolateral view; (3) CEGH-UNC 27080 (on top) and CEGH-UNC 27081 (at bottom) showing part of the body chamber and the incomplete phragmocone; (4-9) CEGH-UNC 27082: disarticulated and incomplete phragmocone, detail of the septum in posterior view, showing the siphuncle, lateral view, showing the suture and the curvature of the septum, ventral view, showing the suture with the ventral lobe and siphuncle, detail of the sutures in ventral view, and general ventral view; (10-12) CEGH-UNC 27089, longitudinal polished section with detail of the septal necks, detail of the chambers and siphuncle, and fragment representing part of the body chamber and incomplete phragmocone, showing the low apical angle and the length of the chambers; (13-15) Bactrites sp., CEGH-UNC 27092, internal mold of part of the phragmocone in a nodule from the lower argillaceous part of the Talacasto Formation (Lochkovian) at Quebrada de las Cortaderas, San Juan: anterior view showing circular cross section, incomplete phragmocone in ventral view showing the sutures, and complete specimen; (16-20) Bactrites sp., PULR-I 1, internal mold of part of the body chamber and incomplete phragmocone preserved in a nodule from the lower argillaceous part of the Talacasto Formation (Lochkovian) at Sierra de las Minitas, La Rioja Province: ventral view, lateral view, detail of the suture and the siphuncle in anterioventral view, detail of the septum and siphuncle in lateral view, and detail of the cross section in posterior view; (21) Bactrites sp., CEGH-UNC 27091 from lower argillaceous interval of the Talacasto Formation (upper LochkovianPragian?) of the Quebrada de las Aguaditas section: ventral view of isolated chamber showing the ventral lobe of the suture and the convexity of the septum; (22-24) Devonobactrites? from greenish mudstones nearly $5 \mathrm{~m}$ above Keidel's bed (early Emsian?) at Loma de Los Piojos section: (22) CEGH-UNC 27098, poorly preserved, dorsoventrally flattened specimen; (23-24) CEGH-UNC 27099, right lateral view, note the oblique septum and suture, and compressed section in posterior view. Scale bars $=5 \mathrm{~mm}(\mathbf{1 - 9}, \mathbf{1 1 - 2 4})$, or $1 \mathrm{~mm}(\mathbf{1 0})$.
} 


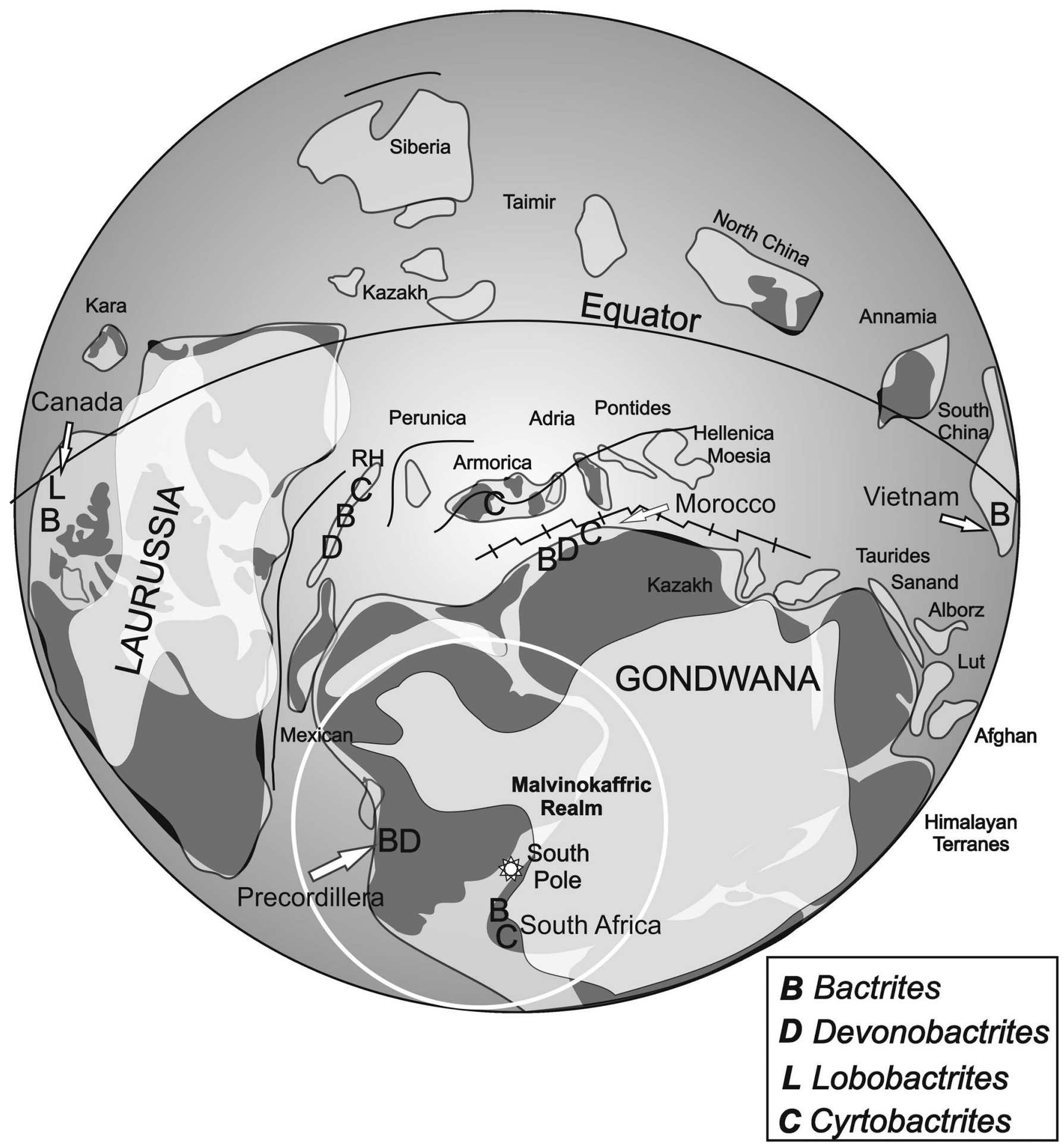

Figure 6. Early Devonian (400 Ma) palaeogeographic reconstruction showing the location of the Malvinokaffric Realm (white circle), and the bactritid genera present at that time, with their occurrences. Modified from Cocks and Torsvicks (2006). RH: Rheno-Hercynian Terrane (Germany). Old Red Sandstone continents in Laurussia and Gondwana indicated in light gray. Records of Bactrites (B) in: Germany (RH), Morocco (Kröger, 2008), Canada* (Telford, 1988), South Africa* (Oosthuizen, 1984), Australia* (Farrell, 1992), Vietnam* (Tong-Dzuy et al., 1988), and Argentine Precordillera (this work). Australia is not in our map's perspective. Records of Cyrtobactrites (C) in: Morocco, France (Armorica), Germany (Klug et al., 2008), and South Africa* (Oosthuizen, 1984). Records of Devonobactrites (D) in: Morocco, Germany (Klug et al., 2008), and Argentine Precordillera (this work). Records of Lobobactrites (L) in: Canada (Prosh, 1987). Note that Eifelian records (or younger) are not reported in the map. *These reports correspond to lists of fossils within stratigraphic works that were taken from the PBDB (The Paleobiology Database: https://paleobiodb.org/\#/) and therefore would need revision.

patterns of global eustacy (Lieberman, 1993). In this context, the new bactritid information provides new insights into a comprehensive interpretation of a number of contrasting paleobiogeographic patterns discussed for different taxonomic groups from these basins. For example, Early and Middle Devonian bivalves from the Argentine Precordillera are widely 
distributed whereas other Malvinokaffric basins record stronger endemic signatures (Sánchez et al., 1995; Sterren et al., 2015). Brachiopods once cited as predominantly Malvinokaffric taxa also exhibit an influence from the Eastern American Realm into the Argentine Precordillera (Herrera and Racheboeuf, 1997; Herrera et al., 1998; Isaacson, 2007). Lower Devonian corals from Bolivia and Argentina do show complex paleobiogeographic affinities (Fernández-Martínez et al., 2007). Middle Devonian ostracodes have a more definite Malvinokaffric imprint than Lower Devonian taxa (Salas et al., 2013; Salas, 2014). With a few exceptions, hyolithids (mainly known from Bolivia) also exhibit Malvinokaffric endemism (Malinky and Racheboeuf, 2011). Trilobites, however, present an overall endemic Malvinokaffric signature, although exceptions have been reported recently (Rustán and Vaccari, 2010, 2012; Holloway and Rustán, 2011).

Ectocochleate cephalopods were planktonic, nektobenthic or nektonic. The chambered shell imposed a limit to habitat or swimming depths, which probably is the reason for some endemism within the group (e.g., Cretaceous nautiloids at a specific level, Cichowolski, 2003). For some taxa, water temperatures might have played a role as a dispersion barrier, as is possibly the case for discosorids and ascocerids (e.g., Kröger, 2013). In ammonoids, the first ontogenetic stage was planktonic and prone to dispersal with oceanic currents. One of the characters that Bactritida and Ammonoidea share is a small embryonic conch, which suggests a planktonic initial stage (De Baets et al., 2012). In turn, bactritids were interpreted as planktonic vertical migrants as adults (e.g., Holland, 2003; Klug et al., 2010). The orientation of the conch would have been nearly vertical (Klug and Korn, 2004), with a slight inclination due to the ventral siphuncle position. The slender conch, small siphuncle, and absence of cameral and siphuncular deposits indicate a low energetic cost of buoyancy regulation. Bactritids would have been adapted to environments with low food availability (Kröger, 2008). In turn, based on the clearly developed muscle attachment scars (Kröger et al., 2005), they were probably capable of slow horizontal movements, but being inefficient swimmers, migrated mainly vertically or drifted passively (Klug et al., 2010). Therefore, from a paleoautoecological point of view, the bactritids were probably capable of migrating with currents during nearly every ontogenetic stage. Thus, the wide distribution of Bactrites gracilis and Devonobactrites, as confirmed by our new records (Fig. 6), indicates that cool waters from the extreme southern paleolatitudes of southwestern Gondwanan seas were not an effective biogeographic barrier for bactritids, in contrast with previous interpretations of Malvinokaffric endemism in co-occurring benthic groups (Boucot and Racheboeuf, 1993). Further studies on the entire cephalopod fauna of the Argentine Precordillera are in progress in order to revise these preliminary conclusions.

The origin and earliest records of bactritids.-The first appearance of bactritids in the fossil record has been repeatedly discussed (see Doguzhaeva, 2002; Holland, 2003; Kröger, 2008; Kröger and Mapes, 2007, and references cited therein). Erben (in Moore, 1964) suggested that the ancestor of bactritids may have been a member of the Orthocerida, which is the consensus opinion today. However, determining which orthocerid group is the bactritid ancestor and when it occurred is an issue of ongoing discussion. The synapomorphies linking Orthocerida and Bactritida are a small subspherical to ovoid initial chamber, the straight to slightly bent conical shell, and the narrow siphuncle (Klug et al., 2015).

The first proposal of an Ordovician origin of the Bactritida, with Eobactrites Schindewolf (=Bactroceras Holm) as the main candidate (Schindewolf, 1932), was repeatedly refuted (e.g., Furnish and Glenister, 1964; Flower, 1964; Dzik, 1984), mainly on the basis of the extended temporal gap existing between these records and Early Devonian representatives of Bactrites. Moreover, Kröger and Mapes (2007), and more recently Aubrechtová (2015), demonstrated that similarities between Bactroceras and the Bactritida are superficial. Aubrechtová (2015) studied more than one hundred specimens of Bactroceras from the Ordovician of the Prague Basin and demonstrated that the protoconch of this genus is morphologically different from that of bactritids from the Devonian. In Bactroceras, the protoconch is moderately large, hemispherical, with a small caecum and a constriction. This differs from those known in bactritids. Both taxa also differ in that bactritids have prominent hyponomic sinuses both in the suture and in the growth lines, and the septa are often inclined. In Bactroceras, the ventral lobe is considered to be a taphonomic artifact because the close proximity of the connecting ring to the phragmocone wall leaves no space for sediment, and consequently a lobe-like structure appears on the internal mold (Aubrechtová, 2015).

Erben (in Moore, 1964) and other authors have placed the origin of the Bactritida in the Silurian, based on the record of a single specimen of Bactrites from the upper Silurian of Morocco (Termier and Termier, 1950). Nevertheless, the specimen was poorly preserved and its illustration unconvincing and not diagnostic as a bactritid. Therefore it was excluded from the Bactritida (Holland, 2003; Kröger and Mapes, 2007). Subsequently, Ristedt (1981) described the species Bactrites bohemicus based on specimens from the Ludlow of Bohemia, but questioned whether that taxon was a direct ancestor of the Devonian bactritids instead of a homeomorph of Devonian Bactrites. The apical morphology of Devonobactrites, currently the oldest well-known Devonian bactritid, from the lower Zlíchovian at Filon Douze in Morocco, supports this opinion (Kröger and Mapes, 2007; Klug et al., 2008). The protoconch of Devonobactrites is elliptical, egg-shaped, and the conch adoral of the apical chamber is slender and displays a cross-sectional diameter less than that of the protoconch. This morphology is similar to that of the apex of Bactrites gracilis (Blumenbach, 1803) (=Orthoceras schlotheimii Quenstedt, 1845; Branco, 1885; Schindewolf, 1933; Kröger, 2008).

Kröger and Mapes (2007) suggested an evolutionary scenario for the bactritids with an origin in Sphaerorthoceras spp. described by Ristedt (1968) from the Upper Silurian, through the Protobactrites sp. from the Lower Devonian of Sardinia (Serpagli and Gnoli, 1977) because both taxa share similar initial chambers, but the siphuncle, which is central in Sphaerorthoceras, becomes eccentric in Protobactrites (Kröger and Mapes, 2007, fig. 8). These authors assumed homeomorphism in the migration of the siphuncle in two lineages: one leading to the Devonian Bactritida, and the other 
from Plagiostomoceras Teichert and Glenister, 1952 through Sphaerorthoceras beatum Ristedt, to 'B.' bohemicus.

Unquestionable bactritids appear at Filon Douze (Morocco) in the lower Zlíchovian (early Emsian), with the abundant presence of Devonobactrites obliquiseptatus Sandberger and Sandberger (Klug et al., 2008; Kröger, 2008). Only a single dubious bactritid fragment was found in Pragian strata, which Kröger (2008) questionably assigned to Bactrites because of the lack of a discernible siphuncle. He explained that due to the small diameter and marginal character of this structure, it is sometimes difficult to identify in small specimens. Other than this questionable record, Klug et al. (2008) suggested that Emsian specimens of Devonobactrites obliquiseptatus are the oldest known bactritids.

Kröger (2008) suggested that the Moroccan record reflects a general pattern because, despite the intensive collecting effort and repeated monographic treatment of Siluro-Devonian cephalopod faunas, no additional bactritid specimens have been reported until now from pre-Emsian strata since the work of Ristedt (1981). Becker and House (1994) drew attention to a questionable Pragian bactritid record in the Rhenish Massif, based on a faunal list in Bender et al. (1974). However, the specimen under question has never been described or reexamined.

Thus, it appears that unquestioned bactritids were previously unknown in pre-Emsian strata with the possible exception of 'Bactrites' bohemicus (Kröger, 2008).

In this scenario, some of our specimens probably constitute the oldest records of the group known at present. As specified above, in the "Stratigraphy and geological setting" section, these earliest records would be Lochkovian. CEGH-UNC 27092 was collected from a concretionary $20 \mathrm{~m}$ thick part of the argillaceous lower interval of the Talacasto Formation at Quebrada de la Cortadera in San Juan Province. This interval contains corals preserved in life position within large lenticular calcareous nodules (up to $50 \mathrm{~cm}$ wide), which are equivalent to the Lochkovian records just $70 \mathrm{~m}$ above the base of the Talacasto Formation in the nearby Quebrada de los Algarrobos, as reported by Carrera et al. (2013). Specimens PULR-I 1-3 were also collected from the lower argillaceous interval of the same unit at Sierra de las Minitas, in La Rioja Province from a shaly marker unit bearing fossiliferous nodules containing Lochkovian trilobites such as Echidnops taphomimus Rustán and Balseiro, 2016 and Talacastops zarelae Edgecombe, Vaccari, and Waisfeld, 1994 (Rustán et al., 2011a, b). In turn, the specimen CEGH-UNC 27089, assigned to Bactrites gracilis, was collected 30 meters below Keidel's bed at the Quebrada de Talacasto locality, of probable Pragian age. The median section of this incomplete conch shows the absence of deposits, the marginal, small and orthochoanitic siphuncle, and the low apical angle, and would be the oldest record of this species. In addition, the moderate abundance of specimens exhibiting undisputed bactritid morphology, and their relative continuity throughout the Lochkovian-Emsian section, does not support a hypothesis of homeomorphy, but accounts for a relatively rich bactritid record in nearly all the Talacasto Formation.

Although important protoconch information typical for the genus is missing in our specimens, the diagnostic adult taxonomic characters of the typical genus Bactrites can be recognized in the Lochkovian. Thus, these earliest records from Argentina close a gap in the fossil record, and "push" the discussions related to the origin of bactritids down into the earliest Devonian, as well as renewing attention to previous Silurian records such as those from Morocco and Bohemia.

In addition, the discovery of relatively abundant bactritids in pre-Emsian strata from high paleolatitudes provides new insights into the probable paleogeographic region of their origin, challenging the previous implicit scenario of a warm-water region of origin where they were more diverse and more widely distributed since the Emsian.

\section{Acknowledgments}

We are very grateful to C. Klug (Zürich, Switzerland) and R.T. Becker (Münster, Germany) for their positive criticism of the original manuscript. Both reviews greatly helped to improve this work. Many thanks to D.M. Work (Associate Editor of the Journal) for his help with English. This work was financially supported by the PICT 1993-2012 (ANPCYT) grant to J.J. Rustán. We are especially grateful to R.T. Becker for discussions and suggestions concerning bactritid taxonomy and biostratigraphy. We also thank C. Klug for bibliographic support and suggestions and B. Kröger (Helsinki, Finland) for bibliographic support. We are grateful to the Argentine researchers who collected specimens described herein: Z. Herrera, B.G. Waisfeld, and N.E. Vaccari (Córdoba, Argentina). M.S. Plastani, S. Adamonis, L. Luci, and A. Caramés (Universidad de Buenos Aires, Argentina) assisted with photography. M. Medina (CICTERRA) prepared polished sections. This is the contribution R-173 of the Instituto de Estudios Andinos "Don Pablo Groeber" (IDEAN).

\section{References}

Astini, A.R., 1991, Sedimentología de la Formación Talacasto: plataforma fangosa del Devónico precordillerano, provincia de San Juan: Revista de la Asociación Geológica Argentina, v. 44, p. 277-294.

Aubrechtová, M., 2015, A revision of the Ordovician cephalopod Bactrites sandbergeri Barrande: systematic position and palaeobiogeography of Bactroceras: Geobios (2015), http://dx.doi.org/10.1016/j.geobios.2015. 03.002 .

Babin, C., 1964, Présence de Lamellorthoceratidae C. Teichert, 1961, dans l'Eifelien du Finistère: Société Géologique de France, Comptes Rendus Sommaires des Séances, v. 4, p. 142-144.

Baker, H.A., 1923, Final Report on Geological Investigations in the Falkland Islands, 1920-1922: Stanley, Government Printer, 38 p.

Baldis, B.A., 1975, El Devónico Inferior de la Precordillera Central. Parte I, Estratigrafía: Revista de la Asociación Geológica Argentina, v. 30, p. $53-83$.

Bandel, K., and Stanley, G.D., 1989, Reconstruction and biostratinomy of Devonian cephalopods (Lamellorthoceratidae) with unique cameral deposits: Senckenbergiana Lethaea, v. 69, 391-437.

Barrande, J., 1846, Notice préliminaire sur le Systême Silurien et les trilobites de Bohême: Leipzig, Hirschfeld, 97 p.

Becker, R.T., and House, M.R., 1994, International Devonian goniatite zonation, Emsian to Givetian, with new records from Morocco: Courier Forschungsinstitut Senckenberg, v. 169, p. 79-135.

Bender, P., Janke, H., and Ziegler, W., 1974, Ein Unterdevon-Profil bei Marburg a. d. Lahn: Notizblatt des hessischen Landesamtes für Bodenforschung, v. 102 , p. $25-45$.

Benedetto, J.L., Rachebouef, P.R., Herrera, Z.A., Brussa, E., and Toro, B., 1992 Brachiopodes et bioestratigraphie de la Formación Los Espejos, SiluroDévonien de la Précordillère (NW Argentine): Geobios, v. 25, p. 599-637.

Beyrich, H., 1850, Arthrophyllum: Zeitschrift der Deutschen Geologischen Gesellschaft, v. 2, p. 10. 
Blumenbach, J.F., 1803, Specimen Archaeologiae Telluris Terra runque Inprimis Hannoveranum: Göttingen, H. Dieterich, 28 p.

Bosetti, E.P., Grahn, Y., Scalise Horodyski, R., Mendlowicz Mauller, P., Breuer, P., and Zabini, C., 2010a, An earliest Givetian "Lilliput Effect" in the Paraná Basin, and the collapse of the Malvinokaffric shelly fauna: Paläontologische Zeitschrift, v. 85, p. 49-65.

Bosetti, E.P., Horodyski, R.S., Zabini, C., Matsumura, W.M.K., and Penteado, A.C., 2010b, Ocorrência de fenótipos subnormais no limite Neoeifeliano/ Eogivetiano, Tibagi, estado do Paraná: implicações tafonômicas e paleossinecológicas: Boletim do Museu Paraense Emílio Goeldi Ciências Naturais, Belém, v. 5, p. 135-149.

Bosetti, E.P., Grahn, Y., Scalise Horodyski, R., and Mendlowicz Mauller, P., 2012, The first recorded decline of the Malvinokaffric Devonian fauna in the Paraná Basin (southern Brazil) and its cause; taphonomic and fossil evidences: Journal of South American Earth Sciences, v. 37, p. 228-241.

Boucot, A.J., 1959, Early Devonian Ambocoeliinae (Brachiopoda): Journal of Paleontology, v. 33, p. 16-24.

Boucot, A.J., and Racheboeuf, P.R., 1993, Biogeographic summary of the Malvinokaffric Realm Silurian and Devonian fossils, in Suarez-Soruco, R., ed., Fósiles y facies de Bolivia v. II. Invertebrados y Paleobotánica: Revista Técnica de YPFB, v. 13-14, p. 71-75.

Bracaccini, O.I., 1950, Observaciones estratigráficas en la Precordillera Sanjuanina: Revista de la Asociación Geológica Argentina, v. 5, p. 5-14.

Branco, W., 1885, Uber die Anfangskammern von Bactrites: Deutsche Geologische Gesellschaft, Zeitschrift, v. 37, p. 1-9.

Braniša, L., 1965, Los fósiles guías de Bolivia: I Paleozoico: Boletín del Servicio Geológico de Bolivia, v. 6, 282 p.

Bustos, U.D., and Astini, A.R., 1997, Formación Punta Negra: análisis secuencial y evolución de la Cuenca Devónica Precordillerana: Revista de la Asociación Argentina de Sedimentología, v. 4, p. 97-111.

Carrera, M.G., and Rustán, J.J., 2016, The new genus Talacastospongia: insights on the first record of a Devonian sponge from South America: Journal of Paleontology, v. 89, p. 912-919.

Carrera, M.G., Montoya, E., Rustán, J.J., and Halpern, K., 2013, SilurianDevonian coral associations across a sequence stratigraphic boundary in the Argentine Precordillera: Geological Journal, v. 48, p. 256-269.

Carvalho, M.D.G.P., 2006, Devonian trilobites from the Falkland Islands: Palaeontology, v. 49, p. 21-34.

Castellaro, H., 1966, Guía paleontológica argentina, Parte I, Paleozoico, Sección III: Faunas Silúricas: Buenos Aires, Publicación del Consejo Nacional de Investigaciones Científicas y Técnicas, $57 \mathrm{p}$.

Cecioni, G., 1953, Contribución al conocimiento de los nautiloideos eopaleozoicos argentinos. Parte I: Protocycloceratidae-Cyclostomiceratidae: Boletín del Museo Nacional de Historia Natural, v. 26, p. 57-109.

Cichowolski, M., 2003, The nautiloid genus Cymatoceras from the Cretaceous of the Neuquén and Austral basins, Argentina: Cretaceous Research, v. 24, p. 375-390.

Cichowolski, M., and Rustán, J.J., 2014, Lower Devonian cephalopods from Precordillera, Western Argentina: Fourth International Palaeontological Congress, Mendoza, Argentina, 2014, Abstract Volume, p. 683.

Clarke, J.M., 1913, Fósseis Devonianos do Paraná: Rio de Janeiro, Monographias do Serviço Geologico e Mineralogico do Brasil, v. 1, 353 p.

Clausen, C.D., 1968, Oberdevonische Cephalopoden aus dem Rheinischen Schiefergebirge. I. Orthocerida, Bactritida: Palaeontographica A, v. 128, p. $1-86$.

Cocks, L.R.M., and Torsvicks, T.H., 2006, European geography in a global context from the Vendian to the end of the Palaeozoic, in Gee, D.G., and Stephenson, R.A., eds., European Lithosphere Dynamics: Geological Society, London, Memoirs 32, p. 83-95.

Cuvier, G., 1797, Tableau élémentaire de l'histoire naturelle des animaux: Paris, Baudouin, $710 \mathrm{p}$

De Baets, K., Klug, C., Korn, D., and Landman, N.H., 2012, Early evolutionary trends in ammonoid embryonic development: Evolution, v. 66, p. 1788-1806.

Doguzhaeva, L., 2002, Adolescent bactritoid, orthoceroid, ammonoid and coleoid shells from the Upper Carboniferous and Lower Permian of the South Urals: Abhandlungen der Geologischen Bundesanstalt, A, v. 57, p. $9-55$.

Dzik, J., 1984, Phylogeny of the Nautiloidea: Palaeontologia Polonica, v. 45, $220 \mathrm{p}$.

Edgecombe, G.D., Vaccari, N.E., and Waisfeld, B.G., 1994, Lower Devonian calmoniid trilobites from the Argentine Precordillera: new taxa of the Bouleia Group, and remarks on the tempo of calmoniid radiation: Geological Magazine, v. 131, 449-464.

Erben, H.K., 1964, Bactritoidea, in Moore R.C., ed., Treatise on Invertebrate Paleontology, Part K, Mollusca 3: Geological Society of America, Boulder, and University of Kansas Press, Lawrence, p. K491-K505.

Erben, H.K., 1966, Über den Ursprung der Ammonoidea: Biological Reviews, v. $41,641-658$.
Evans, D.H., 2005, The Lower and Middle Ordovician cephalopod faunas of England and Wales: Monograph of the Palaeontographical Society, v. 628, p. $1-81$.

Farrell, J.R., 1992, The Garra Formation (Early Devonian: Late Lochkovian) between Cumnock and Larras Lee, New South Wales, Australia: stratigraphic and structural setting, faunas, and community sequence: Palaeontographica A, v. 222, p. 1-41.

Fernández-Martínez, E., Plusquellec, Y., and Castaño de Luis, R., 2007, Corales tabulados del Devónico Inferior de Argentina y Bolivia: estado de la cuestión: Fourth European Meeting on the Palaeontology and Stratigraphy of Latin America, Cuadernos del Museo Geominero, v. 8, p. 143-148.

Feruglio, E., 1930, Il Devonico della regione subandina dell' Argentina settentrionale: XV International Geological Congress, Pretoria, South Africa, 1930, Comptes Rendus, v. 2, p. 568-571.

Flower, R.H., 1964, The nautiloid order Ellesmeroceratida (Cephalopoda): New Mexico Institute of Mining and Technology, Memoir, v. 12, 234 p.

Furnish, W.M., and Glenister, B.F., 1964, Ellesmerocerida, in Moore R.C, ed., Treatise on Invertebrate Paleontology, Part K, Mollusca 3: Boulder, CO and Lawrence, KS, Geological Society of America and University of Kansas Press, p. K129-K159.

García, E., 1945, Estratigrafía y tectónica de la zona situada inmediatamente al SW de Jáchal, Departamento de Jáchal, San Juan [Doctoral Thesis]: La Plata, Facultad de Ciencias Naturales y Museo, Universidad Nacional de La Plata, $88 \mathrm{p}$.

García-López, S., and Fernández-Martínez, E., 1995, The genus Parastriatopora Sokolov, 1949 (Tabulata) in the Lower Devonian of Argentina: paleobiogeographic implications: Geobios, v. 28, p. 175-183.

García-Muro, V.J., Rubinstein, C.V., and Steemans, P., 2014, Palynological record of the Silurian/Devonian boundary in the Argentine Precordillera, western Gondwana: Neues Jahrbuch für Geologie und Paläontologie, Abhandlungen, v. 274, p. 25-42.

Gill, E.D., 1969, Notanopliidae, a new family of Palaeozoic Brachiopoda from Australia: Journal of Paleontology, v. 43, p. 1222-1231.

Grahn, Y., 2002, Upper Silurian and Devonian Chitinozoa from central and southern Bolivia, central Andes: Journal of South American Earth Sciences, v. 15 , p. $315-326$.

Grahn, Y., Mauller, P.M., Bergamaschi, S., and Bosetti, E.P., 2013, Palynology and sequence stratigraphy of three Devonian rock units in the Apucarana Sub-basin (Paraná Basin, south Brazil): additional data and correlation: Review of Palaeobotany and Palynology, v. 198, p. 27-44.

Herrera, Z.A., 1993, Nuevas precisiones sobre la edad de la Formación Talacasto (Precordillera Argentina) en base a su fauna de braquiópodos: Doceavo Congreso Geológico Argentino, Mendoza, Argentina, Actas, v. 2, p. 289-295.

Herrera, Z.A., 1995a, The first notanopliid brachiopod from the South American Devonian sequence: Geobios, v. 28, p. 337-342.

Herrera, Z.A., 1995b, Lower Devonian chonetoidean brachiopods from the Argentine Precordillera, in Racheboeuf, P.F., ed., Four contributions to the study to the Chonetoideans brachiopods: Documents des Laboratoires Géologie, Lyon 136, p. 101-148.

Herrera, Z.A., and Bustos, U.D., 2001, Braquiópodos devónicos de la Formación Punta Negra, en el perfil del Río de las Chacritas, Precordillera Argentina: Ameghiniana, v. 38, p. 367-374.

Herrera, Z.A., and Racheboeuf, P.R., 1997, Afinidades paleobiogeográficas de la fauna de braquiópodos devónica de la Precordillera: Jornadas de Paleontología, v. 13, p. 83-86.

Herrera, Z.A., Salas, M.J., and Giolitti, J.A., 1998, Chilidiopsoidea (Brachiopoda) del Devónico Inferior de la Precordillera Argentina: Revista Española de Paleontología, v. 13, p. 149-166.

Holland, C.H., 2003, Some observations on bactritid cephalopods: Bulletin of Geosciences, v. 78, p. 369-372.

Holloway, D., and Rustán, J.J., 2012, The Trilobite Reedops (Phacopidae) in the Lower Devonian of Argentina (Malvinokaffric Realm): Journal of Paleontology, v. 86, p. $253-257$

Holm, G., 1898, Om ett par Bactrites-liknande Undersiluriska Orthocer-former: Palæontologiska notiser. 179 ser. C. Sveriges geologiska undersökning, p. 354-366.

Horodyski, R.S., Holz, M., Grahn, Y., and Bosetti, E.P., 2013, Remarks on sequence stratigraphy and taphonomy of the Malvinokaffric shelly fauna during the KACÁK Event in the Apucarana Sub-basin (Paraná Basin): Brazil, International Journal of Earth Science, DOI 10.1007/s00531-0130954-9.

Hyatt, A., 1884, Genera of fossil cephalopods: Proceedings of the Boston Society of Natural History, v. 22, p. 273-338.

Isaacson, P.E., 2007, Mid-Paleozoic biogeography of the Central Andes: endemic faunas, immigrants, and paleogeography, in Díaz-Martínez, E., and Rábano, I., eds., $4^{\text {th }}$ European Meeting on the Palaeontology and Stratigraphy of Latin America (Madrid), Cuadernos del Museo Geominero, v. 8, p. 213-218. 
Keidel, J., 1921, Observaciones geológicas en la Precordillera de San Juan y Mendoza: Anales Del Ministerio de Agricultura, Sección Geología, Mineralogía y Minería, v. 15, p. 7-102.

Klug, C., and Korn, D., 2004, The origin of ammonoid locomotion: Acta Palaeontologica Polonica, v. 49, p. 235-242.

Klug, C., Kröger, B., Korn, D., Rücklin, M., Shemm-Gregory, M., De Beats, K., and Mapes, R., 2008, Ecological change during the early Emsian (Devonian) in the Tafilalt (Morocco), the origin of the Ammonoidea, and the firs African pyrgocystid edrioasteroids, machaerids and phyllocarids: Palaeontographica A, v. 238, p. 83-176.

Klug, C., Kröger, B., Kiessling, W., Mullins, G.L., Servais, T., Frýda, J., Korn, D., and Turner, S., 2010, The Devonian nekton revolution: Lethaia, v. 43 , p. $465-477$.

Klug, C., Kröger, B., Vinther, J., Fuchs, D., and De Baets, K., 2015, Chapter 1, Ancestry, origin and early evolution of ammonoids, in Klug, C., Korn, D. De Baets, K., Kruta, I., and Mapes, R.H., eds., Ammonoid Paleobiology: From Macroevolution to Paleogeography: Topics in Geobiology: Springer, v. 44, p. 3-24.

Kolebaba, I., 1999, Sipho-cameral structures in some Silurian cephalopods from the Barrandian Area (Bohemia): Acta Musei Nationalis Pragae, Series B, Historia Naturalis, v. 55, p. 1-15.

Kozlowski, R., 1923, La faune dévonienne de Bolivie: Annales de Paléontologie, v. 12 , p. $1-112$

Kröger, B., 2004, Revision of Middle Ordovician orthoceratacean nautiloids from Baltoscandia: Acta Palaeontologica Polonica, v. 49, p. 57-74.

Kröger, B., 2008, Nautiloids before and during the origin of ammonoids in a Siluro-Devonian section of the Tafilalt, Anti-Atlas, Morocco: Special Papers in Palaeontology, v. 79, p. 5-110.

Kröger, B., 2013, The cephalopods of the Boda Limestone, Late Ordovician of Dalarna, Sweden: European Journal of Taxonomy, v. 41, 110 p. http://dx. doi.org/10.5852/ejt.2013.41.

Kröger, B., and Mapes, R.H., 2007, On the origin of bactritoids (Cephalopoda): Paläontologische Zeitschrift, v. 81, p. 316-327

Kröger, B., and Mutvei, H., 2005, Nautiloids with multiple paired scars from Lower-Middle Ordovician of Baltoscandia: Palaeontology, v. 48, p. 781-791.

Kröger, B., Klug, C., and Mapes, R.H., 2005, Soft-tissue attachments in orthocerid and bactritid cephalopods from the Early and Middle Devonian of Germany and Morocco: Acta Palaeontologica Polonica, v. 50, p. 329-342.

Kröger, B., Vinther, J., and Fuchs, D., 2011, Cephalopod origin and evolution: a congruent picture emerging from fossils, development and molecules: Bioessays, v. 33, p. 602-613.

Le Hérissé, A., Rubinstein, C., and Steemans, P., 1996, Lower Devonian palynomorphs from the Talacasto Formation, Cerro del Fuerte Section, San Juan Precordillera, Argentina, in Patka, O., and Servais, T., eds., Acritarcha in Praha 1996. Proceedings of the International Meeting and Workshop: Acta Universitatis Carolinae Geologica, v. 40, p. 497-515.

Leanza, A.F., 1968, Acerca del descubrimiento de amonoideos devónicos de la República Argentina (Tornoceras baldisi n.sp.): Revista de la Asociación Geológica Argentina, v. 23, p. 326-330.

Lehmann, U., and Hillmer, G., 1980, Wirbellose Tierre der Vorzeit. Leitfaden der Systematischen Paläontologie: Stuttgart, Germany, Ferdinand Enke Verlag, $340 \mathrm{p}$.

Leidhold, G., and Wetten, F., 1947, Sobre el hallazgo del Devónico fosilífero en la Quebrada del Río San Juan: Revista Minera, v. 18, p. 34-40.

Lieberman, B.S., 1993, Systematics and biogeography of the "Metacryphaeus group" Calmoniidae (Trilobita, Devonian), with comments on adaptive radiations and the geological history of the Malvinokaffric Realm: Journal of Paleontology, v. 67, p. 549-570.

Malinky, J.M., and Racheboeuf, P.R., 2011, New Hyolitha from the Devonian of Bolivia: Journal of Paleontology, v. 85, p. 1077-1088.

Mapes, R.H., 1979, Carboniferous and Permian Bactritoidea (Cephalopoda) in North America: The University of Kansas, Paleontological Contributions, v. $64,66 \mathrm{p}$.

Morzadec, P., Mergl, M., Villarroel, C., Janvier, P., and Racheboeuf, P.R., 2015, Trilobites and inarticulate brachiopods from the Devonian Floresta Formation of Colombia: a review: Bulletin of Geosciences, v. 90, p. 331-358.

Niko, S., 2001, Middle Carboniferous orthoconic cephalopods from the Omi Limestone Group, Central Japan: Paleontological Research, v. 5, p. $115-120$

Oosthuizen, R.D.F., 1984, Preliminary catalogue and report on the biostratigraphy and palaeogeographic distribution of the Bokkeveld fauna: Transactions of the Geological Society of South Africa, v. 87, p. 125-140.

Padula, E.L., Rolleri, E.O., Mingramm, A.R.G., Roque, P.C., Flores, M.A., and Baldis, B.A., 1967, Devonian of Argentina, in Oswald, D.H., ed., International Symposium on the Devonian System, Calgary, 1967: Calgary, Alberta Society of Petroleum Geologists,, v. 2, p. 165-199.

Prosh, E.C., 1987, A Lower Devonian ammonoid, Mimagoniatites nearcticus n. sp., from the Canadian arctic: Journal of Paleontology, v. 61, p. 974-981.
Quenstedt, F.A., 1845-1849, Petrefactenkunde Deutschlands. 1. Abteilung, 1. Band, Cephalopoden: Tübingen, Fues Verlag, $580 \mathrm{p}$.

Racheboeuf, P.R., and Herrera, Z.A., 1994, On some new Malvinokaffric Silurian and Devonian chonetacean brachiopods and reclassification of others: Neues Jahrbuch für Geologie und Paläontologie, v. 9, p. 541-560.

Richter, R., and Richter, E., 1942, Die Trilobiten der Weismes-Shichten am Hohen Venn, mit Bemerkungen über die Malvinocaffrische Provinz: Senckenbergiana, v. 25, p. 156-279.

Rickards, R.B., Ortega, G., Basset, M., Boso, M.A., and Monaldi, C.R., 2002, Talacastograptus, an unusual biserial graptolite from the Lipeón Formation (Llandovery, Silurian) of northern Argentina: Ameghiniana, v. 39 , p. $343-350$.

Ristedt, H., 1968, Zur Revision der Orthoceratidae: Akademie der Wissenschaften und Literatur in Mainz, Abhandlungen der MathematischNaturwissenschaftlichen, Klasse 1968, p. 211-287.

Ristedt, H., 1981, Bactriten ans dem Obersilur Böhmens: Mitteilungen aus dem Geologisch-Paläontologischen Institut der Universitat Hamburg, v. 51, p. 23-26.

Rustán, J.J., and Balseiro, D., 2016, The phacopid trilobite Echidnops taphomimus n. sp. from the Lower Devonian of Argentina: insights into infaunal molting, eye architecture and geographic distribution: Journal of Paleontology, v. 90, p. 1100-1111.

Rustán, J.J., and Vaccari, N.E., 2010, The aulacopleurid trilobite Maurotarion Alberti, 1969, in the Silurian-Devonian of Argentina: systematic, phylogenetic and paleobiogeographic significance: Journal of Paleontology, v. 84, p. 1082-1098.

Rustán, J.J., and Vaccari, N.E., 2012, A revision of the Devonian Malvinokaffric dalmanitid trilobite Dalmanitoides Delo, 1935, on the basis of new data from Argentina: Palaeontologia Electronica, v. 15, n. 1, 11A, 21 p.; palaeoelectronica.org/content/2012-issue-1-articles/194-the-trilobite-dalmanitoides.

Rustán, J.J., Vaccari, N.E., and Astini, R.A., 2011a, Early Devonian trilobites from the Sierra de las Minitas, northernmost Precordillera (La Rioja Province), Argentina: Ameghiniana, v. 48, p. 226-241.

Rustán, J.J., Balseiro, D., Waisfeld, B.G., Foglia, R.D., and Vaccari, N.E., 2011b, Infaunal molting in Trilobita and escalatory responses against predation: Geology, v. 39, p. 495-498.

Salas, M.J., 1995, Estudio taxonómico y bioestratigráfico de la fauna de braquiópodos devónicos en el área de Mogote La Cortadera (Sierra de la Deheza), Precordillera de San Juan [Geology Degree Work]: Córdoba, Argentina, Universidad Nacional de Córdoba, $80 \mathrm{p}$.

Salas, M.J., 2014, Lower and Middle Devonian ostracods from South America: their palaeobiogeographical affinities: Fourth International Palaeontological Congress, Mendoza, Abstract Volume, p. 804

Salas, M.J., Rustán, J.J., and Sterren, A.F., 2013, Lower and Middle Devonian Malvinokaffric ostracods from the Precordillera Basin of San Juan, Argentina: Journal of South American Earth Sciences, v. 45, p. $56-68$.

Sánchez, T.M., Waisfeld, B.G., and Toro, B.A., 1995, Silurian and Devonian molluscan bivalves from Precordillera region, Western Argentina: Journal of Paleontology, v. 69, p. 869-886.

Sandberger, G., 1843, Allgemeine Schilderung der paläontologischen Verhältnisse der älteren Formationen Nassaus: Amtlicher Bericht über die Versammlung der Deutschen Naturforscher und Ärzte zu Mainz, v. 20 , p. $154-160$.

Sandberger, G., and Sandberger, F., 1850-1856, Die Versteinerungen des rheinischen Schichtensystems in Nassau, Kreidel und Niedner Verlagsbuchhandlung: Wiesbaden, Kreidel \& Niedner, 564 p.

Schindewolf, O.H., 1932, Zur Stammesgeschichte der Ammoneen: Paläontologische Zeitschrift, v. 14, p. 164-186.

Schindewolf, O.H., 1933, Vergleichende Morphologie und Phylogenie der Anfangskammern tetrabranchiater Cephalopoden. Eine Studie uber Herkunft, Stammesentwicklung und System der niederen Ammoneen: Abhandlungen der Preußischen Geologischen Landesanstalt, Neue Folge, v. 148, p. $1-115$.

Serpagli, E., and Gnoli, M., 1977, Upper Silurian cephalopods from Southwestern Sardinia: Bollettino della Società Paleontologica Italiana, v. 16, p. $153-196$.

Shimansky, V.N., 1951, On the evolution of the upper Paleozoic straight nautiloids: Doklady Akademija Nauk SSSR, v. 79, p. 867-870. [in Russian]

Shimansky, V.N., 1962, Otryad Nautilida, in Ruzhencev, V.E., ed., Osnovy Paleontologii, Molyuski-Golovonogie I.: Izdatelstvo Akademiya Nauk SSR, p. 115-154. [in Russian]

Stanley, G.D., and Teichert, C., 1976, Lamellorthoceratids (Cephalopoda, Orthoceroidea) from the Lower Devonian of New York: The University of Kansas Paleontological Contributions, v. 86, 18 p.

Sterren, A.F., Rustán, J.J., and Salas, M.J., 2015, First Middle Devonian bivalves from Argentina, new records from the Punta Negra Formation and insights on Middle Paleozoic faunas from the Precordillera Basin: Ameghiniana, v. 52, p. 334-349. 
Teichert, C., 1961, Des nautiloides des genres Arthrophyllum Beyrich et Lamellorthoceras Termier et Termier: Annales de Paléontologie, v. 47, p. 93-107.

Teichert, C., and Glenister, B.F., 1952, Fossil nautiloid faunas from Australia: Journal of Paleontology, v. 26, p. 730-752.

Telford, P.G., 1988, Devonian stratigraphy of the Moose River Basin, James Bay Lowland, Ontario, Canada, in McMillan, N.J., Embry, A.F., and Glass, D.J., eds., Devonian of the World, proceedings of the 2nd international symposium on the Devonian System: Canadian Society of Petroleum Geologists, v. 1, p. 123-132.

Termier, G., and Termier, H., 1950, Paléontologie Marocaine. II. Invértébres de l'ère Primaire. Fascicule III, Mollusques: Notes et Mémoires du Service de la Carte Géologique du Maroc, v. 78, 246 p.

Thomas, H.D., 1928, An Upper Carboniferous fauna from the Amotape Mountains, north-western Peru: Geological Magazine, v. 65, p. 289-301.

Thomas, I., 1905, Neue Beiträge zur Kentniss der Devonischen Faunen Argentiniens: Zeitschrift der Deutschen geologischen Gesellschaft, v. 57, p. 233-290.

Tong-Dzuy, T., Dang, T.H., Nguyen, D.H., Nguyen, D.K., Nguyen, H.H., Nguyen, T.D., Ta, H.P., Pham, K.N., and Doan, N.T., 1988, Devonian stratigraphy and coelenterata of Vietnam, 1 - Stratigraphy: Nauka, Novosibirsk, 184 p. [in Russian]
Troth, I., Marshall, J.E.A., Racey, A., and Becker, R.T., 2011, Devonian sealevel change in Bolivia: a high palaeolatitude biostratigraphical calibration of the global sea-level curve: Palaeogeography, Palaeoclimatology, Palaeoecology, v. 304, p. 3-20.

Turner, J.C.M., 1960, Estratigrafía de la Sierra de Santa Victoria y adyacencias: Boletín de la Academia Nacional de Ciencias (Córdoba), v. 41, 262 p.

Vaccari, N.E., Waisfeld, B.G., and Edgecombe, G.D., 1994, Calmoniid trilobites of the Lower Devonian Scaphiocoelia Zone in the Argentine Precordillera: Geobios, v. 27, p. 591-608.

Volkheimer, W., Melendi, D.L., and Salas, A., 1986, Devonian chitinozoans from northwestern Argentina: Neues Jahrbuch für Geologie und Paläontologie, Abhandlungen, v. 173, p. 229-251.

Zhuravleva, F.A., 1961, O redkoj forme kamernykh otlozheniy u devonskikh nautiloidei: Akademija Nauk SSSR, Paleontologicheskij Zhurnal, v. 1, p. 89-94. [in Russian]

Zhuravleva, F.A., 2006, New Devonian Palliocerida (Cephalopoda, Astrovioidea): Paleontological Journal, v. 40, p. 617-625.

Accepted 6 March 2017 